\title{
Philanthropic Campaigns and Customer Behavior: \\ Field Experiments on an Online Taxi Booking Platform
}

\author{
Jasjit Singh \\ Associate Professor, INSEAD \\ jasjit.singh@insead.edu \\ +6567995341
Nina Teng
DPhil Candidate, University of Oxford
nina.teng@ouce.ox.ac.uk
+441865285066 \\ Serguei Netessine \\ Professor, INSEAD \\ serguei.netessine@insead.edu \\ +6567999225
}

May 31, 2017

Forthcoming, Management Science

We are grateful to INSEAD Randomized Control Trials Lab and INSEAD R\&D Committee for funding this research, and to the employees of our research site for their support. We thank seminar participants at Asian Management Research Consortium, Nanyang Technological University, National University of Singapore and INSEAD for their insightful feedback. We also thank Arzi Adbi, Christiane Bode, Pierre Chandon, Ziv Carmon, Chirantan Chatterjee, Donal Crilly, Nagalakshmi Damaraju, Pushan Dutt, Daniel Elfenbein, Karan Girotra, Maria Guadalupe, Leena Kinger Hans, Zoe Kinias, Amine Ouazad, Phanish Puranam, Craig Smith, Olav Sorenson, Stephan Thau, Heli Wang and Andy Yap for their helpful suggestions. Finally, we are grateful to editors and reviewers at Management Science for their excellent and very constructive comments. Errors remain our own. 


\begin{abstract}
Firms commonly undertake philanthropic campaigns as a means of attracting and retaining customers. Such campaigns often take the form of charity-linked promotions, whereby a firm donates a specific amount to a charitable cause when a customer takes up the promotion through a related purchase. We carried out three field experiments to study such promotions in the context of an online taxi booking platform. Customers were randomly assigned to different treatment groups, which received either a charity-linked or a discount-based promotion from a range of monetary amounts. Take-up rates for charity-linked promotions were not only much smaller than for discount-based promotions but also less sensitive to the exact amount involved, consistent with a view that the decision to take up a charity-linked promotion was driven in part by a "warm glow" from mere association with giving. We also find a selection effect in promotion take-up: charity-linked promotions were disproportionately taken up by people who had already been more active customers. Although a promotion take-up does seem to represent new demand rather than mere substitution of a booking that would have occurred anyway, longitudinal data analysis reveals little evidence of a lasting treatment effect on long-term demand beyond the promotion period for either kind of promotion. Given the high cost relative to benefit for the promotional bookings themselves, this finding raises concerns regarding the prevalent practice of firms devoting significant funds for short-term promotions without rigorously examining their exact impact.
\end{abstract}

Keywords: corporate philanthropy, corporate social responsibility, field experiments, customer behavior, online marketplaces 


\section{INTRODUCTION}

The issue of how much corporate social responsibility (CSR) activities contribute to firm performance remains unresolved despite much academic debate (Margolis, Elfenbein and Walsh, 2009). Nevertheless, firms continue to devote significant resources to CSR, often driven by an expectation of commercial returns and not just altruism (Eccles, Ioannou and Serafeim, 2014; Servaes and Tamayo, 2013). One common manifestation of CSR initiatives is philanthropic campaigns intended to increase customer demand and loyalty (Du, Bhattacharya and Sen, 2011; Lev, Petrovits and Radhakrishnan, 2010; Sheikh and Beise-Zee, 2011). Our study examines one such initiative in the context of a taxi booking company. We employ field experiments to enable a causal interpretation of our data and analysis, which would not have been possible if relying just upon correlations among different variables based only on archival data. Classic examples of firms relying on philanthropic campaigns include the 1976 launch of Marriott's 'Great America' entertainment center while supporting the March of Dimes, and a 1983 American Express effort to engage its customers by donating a certain amount towards renovation of the Statue of Liberty upon every usage of its cards (Advertising Age, 2003). More recent examples include Hanes supporting The Salvation Army, Dunkin Donuts supporting the Special Olympics and Kmart supporting St. Jude Children's Research Hospital. In North America alone, the overall size of charitable giving involving such initiatives has grown from just \$100 million in 1990 to almost $\$ 2.0$ billion in 2015, with the recent growth rate of about 4\% per annum indicating a continued upward trend (IEG, 2015).

The "business case" for philanthropic campaigns relies on an assumption that customers are attracted to firms engaging in societal issues. Empirical research in behavioral economics has established that people do generally demonstrate some prosocial preferences (Andreoni and Payne, 2013; Erat and Gneezy, 2011; Gneezy, Imas and Madarasz, 2014; Meier, 2007). On the specific issue of how this affects consumer behavior, at least some customer segments might exhibit preference for engaging in societal issues through their purchasing choices (Hainmueller and Hiscox, 2012a, 2012b). However, disentangling such effects from other drivers of consumer behavior is empirically challenging. For example, although studies in the context of online markets find a price premium for products associated with a positive impact (e.g., through Fair Trade certification), this is driven not just by prosocial preferences but also other factors like signaling related to quality (Elfenbein and McManus, 2010; Hiscox, Broukhim and Litwin, 2011). ${ }^{1}$

\footnotetext{
${ }^{1}$ Identifying effects related specifically to prosocial preferences can be easier in a laboratory setting. For example, Bartling, Weber and Yao (2015) use laboratory experiments to demonstrate a preference among many participants (assigned to roles as producers or consumers) for avoiding negative social impact, reflected both in the composition of product types (i.e., producers accepting higher cost for production to reduce negative externalities) and in the demand for responsible products (i.e., consumers accepting a price premium for products with less externalities).
} 
Many surveys claim that customers appreciate the opportunity to contribute to social causes through their buying choices (Cone, 2015; MLSGROUP, 2014). However, business scholars have questioned whether one-off philanthropic campaigns unrelated to a firm's core business are an effective way of corporate social engagement (Porter and Kramer, 2002, 2011). Nevertheless, use of such campaigns continues to be widespread, even though rigorous academic evidence regarding their effects is still limited. To fill this gap, our study combines a field experiment approach and longitudinal analysis of individual-level customer data to examine whether and how philanthropic campaigns affect commercial outcomes. Our study is based on three field experiments executed with the help of a leading online taxi booking company in Asia. We used text messages (SMS) to send different promotion codes to randomly selected groups of existing customers from the company's database. The experiments allow an examination of charity-linked promotions involving different donation amounts, and were replicated using two different charitable causes. While many studies have examined charity-linked campaigns (Karlan and List, 2007; Andreoni and Payne, 2013; Gneezy, Imas and Madarasz, 2014), our study contributes to the relatively nascent literature considering these specifically in a business setting. We build upon a study by Elfenbein, Fisman and McManus (2012), who examine the effect of links to charity on sale of products on eBay. We extend their line of investigation to consider not just immediate take-up but also whether the association with charity affects subsequent demand. This is a particularly important consideration for contexts (like ours) where a one-time take-up by the customer might not be enough to justify the cost of a campaign.

Our research also has close links to the literature on cause-related marketing, which takes philanthropic initiatives as a complement to traditional advertising and brand-building efforts (Bronn and Vrioni, 2001; Sheikh and Beise-Zee, 2011; Varadarajan and Menon, 1988). Our key distinction is examining not just take-up of promotions but also associated longitudinal patterns of overall purchases, while comparing selection and treatment effects across a range of charity-linked promotions as well as discount-based promotions offering customers a price rebate instead (Acquisti and Varian, 2005; Barone and Roy, 2010). Online marketplaces comprise an interesting empirical context for us since such platforms have grown to be a significant part of the economy and continue to aggressively employ promotions in the hope of building customer loyalty and market share. For example, a recent report put Uber's marketing expenses at \$246 million for 2014 and \$295 million for the first half of 2015, with promotions and rebates alone costing \$57.3 million and \$72 million respectively during these periods (Solomon, 2016).

Methodologically, our paper adds to research employing experimental approaches to examine different aspects of corporate social engagement (Burbano, 2016; Hossain and $\mathrm{Li}, 2014$ ). This approach derives conclusions based on preferences as revealed through actual decisions, which are more accurate than selfreported preferences (Lazear, Malmendier and Weber, 2012). The reliability of our conclusions is further 
enhanced through use of field experiments embedded in a real firm's operations (Harrison and List, 2004; Chatterji, Findley, Jensen, Meier and Nieldson, 2016): not having to rely on stylized tasks or special subject pools helps overcome many challenges laboratory experiments face (Charness, Gneezy and Kuhn, 2013; Levitt and List, 2007). Nevertheless, since mechanisms can be harder to isolate in the field and some findings might be specific to a context, we view field studies like ours as complementary to rather than a substitute for other approaches used in the cumulative body of research (Charness and Fehr, 2015).

We find take-up for charity-linked promotions to be much smaller than for discount-based promotions, and more likely to come from customers that are already frequent users of the company's services. Although take-up rates do go up with the monetary amount involved in both kinds of promotions, this sensitivity is smaller for charity-linked promotions than for discount-based promotions. In subsequent longitudinal analysis, we examine whether there is an increase in a customer's daily taxi booking frequency in the days following a promotion, an effect we might expect to be particularly strong for charity-linked promotions if they do enhance a firm's reputation or brand as often claimed. Although we find a promotional booking to generally represent new purchase rather than mere substitution of a booking that would have occurred anyway, we find little evidence of an overall increase in subsequent bookings or of charity-linked promotions being more effective than discount-based promotions.

Given the absence of a multiplier effect beyond the promotional booking and the high cost of executing each promotion, the cost-benefit equation does not stack up favorably for any of the promotions in our study. To address a possible concern that our interventions might have been weak, we repeat our analyses just for customers that received promotions twice across experiments, and our findings remain essentially unchanged. At a minimum, our study therefore provides a reason to be skeptic and cautious regarding any "business case" that is just taken for granted in the often-indiscriminate spending on promotions.

\section{HYPOTHESES REGARDING CHARITY-LINKED PROMOTIONS}

Promotion take-up rates can serve as a short-term measure for how a campaign is received, possibly being a leading indicator of longer-term benefits it might bring. Therefore, our first two hypotheses consider take-up rates of charity-linked promotions of varying amounts, and how these compare against discountbased promotions. For two additional hypotheses, we focus on longitudinal patterns in the customers' purchase behavior, comparing daily purchase frequency before, during and after the promotion period.

\subsection{Customer Take-Up Rates for Different Promotions}

Customers taking up charity-linked promotions effectively incur some form of cost even if the amount to be paid to the charity comes from the firm's budget. This might, for example, involve an economic cost 
(e.g., paying for the taxi ride rather than taking public transport or walking) or a psychological cost (e.g., switching from a competing service that the customer is used to). Even if the customer were going to make the purchase from the firm anyway, there is at least the mental effort of recalling the specific promotion code (sent, for example, via an SMS-based text message) and using it accurately at the time of purchase even if it is slightly time-consuming (e.g., typing it in a mobile app when making a booking).

If the promotion take-up process is standardized across amounts and the firm is the one donating to the cause (conditions met in our empirical context), the cost to a customer of taking up a promotion is independent of the amount. Yet the altruistic customer should perceive an unambiguous increase in his or her utility as the monetary amount goes up, since a larger amount donated to the cause represents a bigger social impact that should lead to a pro-social customer feeling better about the purchase. While the threshold at which it is worthwhile to make the effort to take up a promotion will vary from one customer to another, the fraction of people for which this threshold will be crossed should monotonically increase as the amount involved goes up. This leads to our first (relatively straightforward) hypothesis:

\section{Hypothesis 1. The take-up rate for a charity-linked promotion will go up with the monetary amount that the firm gives to the charity when the customer makes a purchase.}

Even if take-up rates increase with the amount, their absolute level need not be large. In interpreting prior research, Devinney, Auger and Eckhardt (2010) conclude that the common image of customers caring a lot about social impact is exaggerated: such effects are prominent either in niche segments or in scenarios involving comparable product offerings. A recent study by Hainmueller, Hiscox and Sequiera (2015) similarly finds customer willingness to pay a premium for social impact to vary by customer segment as well as other product attributes. Newman, Gorlin and Dhar (2014) argue that over-emphasizing social impact as a core feature can even hurt business if customers perceive this as compromising quality.

We expect customers to generally value private benefit for themselves (as a discount) more than an equivalent amount going to charity. The theory of "warm glow" nuances our expectation regarding the relative extent to which the amount involved ought to matter by recognizing that there is a qualitative difference in intangible benefits generated when prosocial behavior is involved: an individual derives significant utility from the mere act of helping others, independent of the benefit achieved for society (Andreoni, 1990; Carson, 2012; Meier, 2007). Survey-based research on how much people care for nonmarket goods, such as a widely-cited study by Desvousfes et al. (1993) asking for their willingness to pay for an initiative for protecting wildlife, has found limited correlation between the financial sacrifice people accept and their scale of impact. Kahneman, Ritov and Schkade (1999) argue that this human tendency towards "scope neglect" might be explained in terms of the psychological process of "affective 
valuation", where the quantitative aspect of the impact might not be as salient. Hsee and Rottenstreich (2004) make a similar argument in distinguishing between "valuation by calculation" and "valuation by feeling", with decisions involving societal impact often falling into the latter category.

Recent experimental studies have provided further evidence consistent with a view that the extent of help provided is only a part of the equation explaining prosocial behavior: the mere act of having helped drives much of the utility (Null, 2011; Karlan and Wood, 2016; Tonin and Vlassopoulos, 2010). Thus we should expect that the ratio of the marginal utility from facilitating a benefit for others (through charity) to the marginal utility from a comparable benefit to oneself should decrease as the amount involved increases. Consistent with this argument, Imas (2014) finds using donation to charity (in return for an agent putting in extra work) to be effective as an incentive when the monetary amount involved is small, but direct payment to the agent becomes a more effective incentive for a larger amount involved. Applied to our setting, similar reasoning implies that, even if customers care about a charitable cause, their sensitivity to the amount going to charity should matter less than it would be if they received a discount instead. In other words, increasing the amount would have a weaker effect on increase in take-up of charity-linked promotions than of discount-based promotions. We state this formally as our second hypothesis:

\section{Hypothesis 2. The promotion take-up rate will be less sensitive to the monetary amount for charity-linked promotions than for discount-based promotions.}

\subsection{Customer Demand Patterns Associated with Different Promotions}

A critical issue beyond promotion take-up is how subsequent demand is affected by the intervention. Hence, we next turn to examining how charity-linked promotions might affect customer purchases in the period following the promotion, and how any such effects compare with those for discount-based promotions. From a commercial point of view, the take-up of a promotion - whether charity-linked or discount-based - is not the ultimate goal (even if it serves as a leading indicator of a campaign's likely impact). For example, if promotion take-up only represents purchases substituting for non-promotion purchases that would have taken place anyway, their demand-generation rationale is not met.

The real expectation of commercial value of charity-linked promotions, even if their take-up rates are low, lies in a potential multiplier effect in terms of increased purchasing frequency beyond the promotion itself. A study by Arora and Henderson (2007) finds evidence supporting a view that such cause-related marketing can indeed serve as an effective sales promotion strategy. Similarly, Krishna and Rajan (2009) find that charity-linked promotions boost profitability even in a competitive setting, and that a customer's willingness to pay for the firm's products can in fact increase even for products beyond those directly 
involved in the promotions. Such findings are consistent with broader research demonstrating how social engagement activities in general can be a means of improving a firm's image and brand equity with customers (Brown and Dacin, 1997; Hoeffler and Keller, 2002; Sen and Bhattacharya, 2001).

The desire to contribute to a social cause may only be one aspect of the mechanism driving customer participation in charity-linked promotions. A related aspect, in fact one that might be more critical from the point of view of long-term business outcomes, is a reinforcing of the identification of customers with the firm running such social initiatives (Lichtenstein, Drumwright and Braig, 2004; Luo and Bhattacharya, 2006; Sen and Bhattacharya, 2001). Associating itself with a cause can serve as a way for a firm to raise its reputation with diverse stakeholders, including customers who are able to identify with the firm and the cause it supports (Arnett, German and Hunt, 2008; Shang, Redd and Croson, 2008). This identification is central to the logic of using charity-linked promotions as a marketing tool analogous to traditional advertising and other brand-building tools (Bronn and Vrioni, 2001; Sheikh and Beise-Zee, 2011; Varadarajan and Menon, 1988). These arguments lead us to our next hypothesis, which pertains to the long-term and lasting effect of the promotional intervention (beyond just the promotion take-up itself):

\section{Hypothesis 3. A charity-linked promotion will lead to a net increase in a customer's overall} demand (i.e., total purchase during and after the promotional period) for the firm's services.

Although charity-linked promotions are used often, discount-based promotions remain more prevalent and on average constitute more than half of a firm's overall marketing budget (Ailwandi, Harlam, Cesar and Trounce, 2006). Such promotions rely upon adoption being boosted as the customer finds a product worthwhile upon use, and are credited with indeed having helped improve important marketing metrics like sales volume and store traffic in many instances (Aribarg and Arora, 2008). However, an excessive focus on discounts also carries the risk of accentuating price sensitivity and leading to brand erosion, especially if multiple rivals start to compete through aggressive discounts (Blattberg and Neslin, 1990).

In contrast to discount-based promotions, charity-linked promotions are believed to help a firm better differentiate through a perception of societal engagement (Bronn and Vrioni, 2001; Hull and Rothenberg, 2008; Sheikh and Beise-Zee, 2011; Varadarajan and Menon, 1988). The psychological processes underlying take-up of charity-linked promotions are therefore expected to involve greater loyalty in subsequent customer behavior (White and Peloza, 2009; Winterich and Barone, 2011), hence increasing customer demand without having the risk of negative side effects that price discounts carry (Arora and Henderson, 2007; Henderson and Arora, 2010; Krishna and Rajan, 2009). If the underlying product is significantly more expensive than alternatives, such effects might be further boosted if customers taking up a charity-linked promotion feel so good about having helped others that they subsequently splurge 
more on themselves (Mazar and Zhong, 2010). For example, in the context of taxi booking, they might be more willing to spend money on another taxi ride rather than going back to using public transport.

Integrating the above arguments, we might form an expectation that customers attracted through charitylinked promotions are more loyal than those taking up discount-based promotions. In other words, even if the fraction of customers that take up a promotion is smaller for a charity-linked promotion than a discount-based promotion of a comparable amount, the charity-linked promotion might still be on the whole more effective as a loyalty-building tool in terms of having a larger and more lasting effect on the long-run demand (beyond just the promotion take-up itself). This leads to our final hypothesis:

Hypothesis 4. For relatively altruistic customers, the net increase in overall demand (i.e., total purchase during and after the promotional period) associated with a charity-linked promotion will be greater than that for a discount-based promotion involving the same monetary amount. ${ }^{2}$

\section{EMPIRICAL APPROACH}

We carried out field experiments in collaboration with a leading online taxi booking company in Asia. The company's automated smartphone-based booking and dispatch platform had attracted significant investor funding, a large chunk of which was being spent on enticing and retaining users. Although relatively young, the company was already one of the leading taxi booking platforms in Asia, with a network of over 200,000 drivers and several million customers across multiple countries. (Company's identity or detailed financial and operational data cannot be revealed for confidentiality reasons.)

\subsection{Design of the Field Experiments}

We implemented three field experiments as a part of the company's Singapore operations. Among its locations of operation, Singapore was the most comparable to major Western countries (for example, in terms of per capita income and transport infrastructure). Our experiments involved 260,504 customers

\footnotetext{
${ }^{2}$ In terms of the impact of charity-linked promotions on business, what matters is not just how the altruistic customers behave but also what fraction of the customers are in reality altruistic. There is likely to be significant heterogeneity across customers, but the exact fraction of customers that are altruistic is unknown. An unambiguous theoretical prediction regarding the combined (average) effect for the entire customer base is thus not feasible. Our hypothesis development has therefore focused mostly on the relatively altruistic customers, leaving the question of combined (average) effect as the empirical issue to be practically examined in our data analysis later in the paper.
} 
drawn as a random subset of the company's Singapore-based customers who had made at least one taxi booking during Jan 1-May 22, 2015, and were not on a "do not call" list uncontactable for marketing. ${ }^{3}$ In each experiment, customer groups were sent private text messages (SMS) on their registered phone numbers, and a promotion code received could be redeemed just once and only through a taxi booking within the next five days. The experiments involved two different charitable causes: raising funds for victims of two major earthquakes in Nepal in 2015 (the first two experiments, with promotion periods 2731 May and 04-06 June respectively), and giving to a local charity called Singapore Cancer Society (the third experiment with a promotion period 06-10 October). ${ }^{4}$ The appendix (Tables A-1a, A-1b and A-1c) reproduces the text of all the messages we sent to random groups of customers in each experiment.

All promo codes were valid for only one-time redemption during the respective five-day promotion period. The promotions were executed truthfully as a part of the company's operations: customers using a discount-based promotion code for a taxi booking got a price rebate as promised, and their use of a charity-linked code triggered a real donation of the stated amount to the supported cause. The SMS messages were private, and gave no indication of whether and how many other customers had received the promotion. This anonymity was designed to get at mechanisms beyond just peer pressure or social desirability considerations (which can be effective for raising funds too, but are not the focus here). ${ }^{5}$

We constructed customer groups for the first two experiments through a single randomization process involving all 260,504 customers. In the first experiment, 95,540 customers (randomly drawn and divided into five equal groups with different codes) were sent an SMS with a promo code, and 19,107 customers (randomly drawn to serve as the "No promocode" control group) sent one without any promo code. In the second experiment, 64,000 customers (randomly drawn and divided into three groups using stratified sampling) were sent an SMS with a promo code, and 28,000 customers (serving as the "No SMS" control group) sent one without any promo code. The remaining 53,857 customers were sent no SMS at all in either experiment 1 or experiment 2, and serve as another control group for both experiments.

\footnotetext{
${ }^{3}$ Customers on this list are likely to have systematically different preferences, so our results apply to the population of customers not on this list. However, this is the relevant population for managerial implications anyway, given that the company can in any case send marketing promotions only to people not on the list.

${ }^{4}$ The two causes - one global and another local - were selected after extensive conversations with the Public Affairs (CSR) team and the marketing staff regarding the causes expected to generate most local interest. But formally examining design of effective charitable promotions is beyond the scope of our study as it is a major topic in itself, with illustrative studies being Anik, Norton and Ariely (2014), Asensio and Delmas (2014), Gneezy, Gneezy, Nelson and Brown (2010), Goldstein, Cialdini and Griskevicius (2008) and Ryzhov, Han and Bradic (2015). ${ }^{5}$ In the first two experiments, we observed a few "illegal" uses of a code by customers not meant to get the code, as the company's IT system was not yet designed to prevent such misuse. So we manually excluded these relatively rare observations ( 21 in experiment 1 and 14 in experiment 2 ) from our samples for analysis. By experiment 3, the IT system had been enhanced to simply deny illegitimate use of a promotion code, so this became a non-issue.
} 
Table 1a provides further details for the "All Customers" sample described above. We also construct an "Active Customers" sample comprised of a subset of these individuals who had made at least one taxi booking in the four weeks leading up to the respective intervention. As Table 1a shows, take-up rates for “Active Customers" are consistently greater than for "All Customers" sample, i.e., customers that had been active users of the booking platform recently were also more likely to take up our promotions.

Since our first two experiments "used up" our initial list of 260,504 customers, experiment 3 involved fresh randomization to reallocate all these customers into new groups. As summarized in Table 1b, 177,500 randomly chosen customers from the overall list (divided into six groups using stratified sampling) were sent an SMS with a promo code, another random subset of 50,000 were sent an SMS without a promo code (serving as the "No promocode" group for experiment 3), and the remaining 33,004 customers were not sent any SMS at all (hence serving as the "No SMS" group for experiment 3).

Having randomization redone for experiment 3 implies that there is a partial overlap between each group in experiment 3 and each group in experiments 1 or 2 (see Table A-2.) This allows us to construct a "Multi-Promo Customers" sample for additional analysis on effects of receiving multiple promo codes. Specifically, the treatment groups for this sample (in light grey shading in Table A-2) are comprised of individuals who received a charity promo in either experiment 1 or experiment 2 and received any promo code in experiment 3. The control groups (in dark grey shading in Table A-2) now include "No promocode" or "No SMS" customers from experiment 3 that had not received any SMS earlier (i.e., were also in the "No SMS" group for the first two experiments). Comparing these treatment and control groups will form the basis for identifying effects associated with receiving two promo codes. ${ }^{6}$

\subsection{Longitudinal Datasets}

The company also provided us with data on all bookings made by the 260,504 customers during 2015 . This makes it feasible to carry out analyses of not just promotion take-up rates but also longitudinal taxi booking patterns (taking customer-day as the unit of analysis). To accomplish this, we merged promotion take-up data into the overall data on daily bookings to construct a longitudinal dataset corresponding to each experiment. Recall that each experiment includes two control groups: "No promocode" customers sent an SMS without any promo code and "No SMS" customers not sent any SMS at all.

\footnotetext{
${ }^{6} \mathrm{We}$ could, in principle, have also constructed an analogous sample of experiment 3 customers that had received a discount promotion earlier. However, given the highly noisy data, such a sample is not statistically meaningful as there were just 8,000 individuals in the only group ("1off") that had received a discount promo before experiment 3 . ${ }^{7}$ We use both groups in all our regressions, using the group not sent any SMS as the omitted category and using an indicator for the group sent an SMS without any promotional code. The coefficient estimate for this indicator is never statistically significant, implying that the two groups are indistinguishable as far as our analysis is concerned.
} 
As detailed in the appendix (Table A-3), each of our three constructed datasets relies on a 61-day window of coverage: the 28-day period just prior to the promotion period, the actual five-day promotion period and the 28-day period right after the promotion period. ${ }^{8}$ As Lewis and Reiley (2014) note in the related context of online advertising, the effects from a marketing campaign might be strongest right after an intervention. In choosing a 28-day post-intervention window, we balance this consideration with the fact that choosing too short a window might lead to loss of statistical power. (In analysis not reported here, our regression estimates are qualitatively similar but often with lower p-values with a 14-day window). ${ }^{9}$

We take daily bookings (a count of a customer's taxi bookings in a day) as our first dependent variable, as the relevant financial transaction from the point of view of the taxi company in our context involves a flat fee the driver pays the company for every booking done through the mobile app. (This flat fee is under SGD 1, the precise amount not being reported here for confidentiality reasons.) Our analyses also employ daily fare (the overall taxi money spent per day by a customer) as an alternate dependent variable, as that might be more directly comparable with other such studies in different contexts. ${ }^{10}$

Although our randomization ensures that such unobserved heterogeneity is not a concern in estimating treatment effects, we create a few customer-level variables our data do allow: recent booking history (cumulative number of bookings made in the 28 days leading up to the given intervention), customer tenure (how long a person had been a customer, measured as a real number in years as of the start of our respective experiment), past promotion takeup (an indicator for whether the customer had ever taken up a promotion code in any past marketing campaign before our given intervention) and apple device (whether the customer had made his or her last booking prior to our given intervention using a device from Apple).

As Table A-4 details, average values of the above observed variable are similar across treatment and control groups within each experiment (though sometimes vary across experiments as a definition might be time-variant, e.g., for customer tenure). This serves as a check that randomization had worked well. The statistics also provide insight into typical customer profile: considering those receiving a charity

\footnotetext{
${ }^{8}$ The only exceptions are just a few customers that entered our database through a first ride between April 30 and May 22 (the last date of any new customers entering our database coverage), for which we have daily observations only after they started. All findings reported here are robust to simply dropping these customers.

${ }^{9}$ Our conversations with executives of the taxi platform indicated that marketing campaigns in fast-moving online contexts like theirs are typically carried out with potential effects to be realized within a few weeks in mind, leading us to choose two-week (14 days) and four-week (28 days) post-intervention time windows for our analyses. Our choices are also similar to those made by Lewis and Reiley (2014) in their study on the impact of online advertising. ${ }^{10}$ Our taxi fare information is in Singapore dollars or SGD (1 SGD being about 0.73 USD on average during 2015). The average taxi ride cost between SGD 16 and 18 across the three experiments, and the corresponding figure just for people taking up promotions was not too far off from the population average in each case. All our fare-related analyses are based on estimated fare a customer is provided at the time of booking, based on pick-up and drop-off locations. The final payment between the passenger and the driver (typically in cash) is based on the taxi meter, and not reported back to the company. Tipping is not common in Singapore, and tips are small when they do occur.
} 
promotion in experiment 1 , the average person had made 3.21 bookings in the 28 days prior to the intervention, had been a customer with the company for 0.53 years, had a $7 \%$ likelihood of having taken up a past promotion, and had a 59\% likelihood of having made their last booking using an Apple device.

\section{ANALYSIS OF PROMOTION TAKE-UP RATES}

\subsection{Promotion Take-up: Experiments 1 and 2}

As summarized in Table 1a, the charity-linked promotions employed in our first two experiments involved supporting Nepal earthquake relief. Experiment 1 employed five promotional codes (sent to 19,108 customers each), with a donation amount of SGD 1, 2, 3, 4 and 5 respectively. Experiment 2 used two promotional codes (sent to 28,000 customers each), with a donation amount of SGD 1 and 7 respectively, refining experiment 1 design using better standardization of the promo codes (as explained below). Experiment 2 also included an additional treatment group that received a discount promotion for SGD 1 (sent to a smaller group of 8,000 customers, with an expectation of a greater take-up rate than charity codes), allowing a comparison of charity-linked promotions with discount-based promotions.

The average take-up rates for experiment 1 are reported in Table 1a, and depicted graphically in Figure 1a (with a formal statistical comparison across promotions postponed till our regressions later). For both the "All Customers" sample and the "Active Customers" sample, relative take-up rates for "1Nepal" (SGD 1 to Nepal relief) versus "Nepal5sgd" (SGD 5 to Nepal relief) are in line with Hypothesis 1 that take-up rates ought to be larger for bigger charity amounts. However, we do not see a strictly monotonic increase across all amounts. For example, "Nepal3sgd" and "4sgd" take-up rates deviate from what the trend from "1Nepal" to "2sgd" suggests. We see two plausible reasons for this anomaly. First, as the ethnic majority in Singapore is Chinese, the attractiveness of the " $4 \mathrm{sgd}$ " promotion might be reduced by the fact that four is considered an unlucky number (representing death) in Chinese culture. ${ }^{11}$ Second, the code "Nepal3sgd" is more complex than a code like "2sgd", likely contributing to a downward bias in its take-up. To avoid a repetition of this issue, we chose more standardized codes ourselves in Experiments 2 and 3, rather than again leaving it up to the company's marketing team to come up with the codes. ${ }^{12}$

Table 1a also reports the take-up rates for experiment 2 promotions, and the results are shown graphically as Figure 1b. The take-up rate for the SGD 1 charity-linked promotion is now lower than in experiment 1 ,

\footnotetext{
${ }^{11}$ See Hirshleifer, Jian and Zhang (2016) for an empirical demonstration of how such superstitions can indeed lead to real differences in outcomes related to decision making in the context of Chinese culture.

${ }^{12}$ How a promotion is worded could also affect its take-up rate. For example, experiment 1 text saying "Promo ends 31 May..." might have created a sense of urgency that increased take-up rates. To minimize the chance of difference in wording across messages leading to biases, our analyses rely upon relative take-up rates across conditions where both the text and the promo codes had been standardized as much as possible (especially in experiments 2 and 3 ).
} 
possibly a reflection of the longer time elapsed since the Nepal earthquakes. ${ }^{13}$ However, we still find support for Hypothesis 1 as the charity-linked promotion take-up rate is again larger for the bigger amount. It is also reassuring that the ratio of take-up rates for " $7 \mathrm{sms}$ " and " $1 \mathrm{sms}$ " in experiment 2 is just a bit greater than the ratio for "Nepal5sgd" and "1Nepal" in experiment 1.

Experiment 2 also allows comparing our discount promotion with charity-linked promotions. Considering the "All Customers" sample, it is striking that the take-up rates for SGD 1 as a price discount are almost twelve times that for SGD 1 going to charity, and six times that for even SGD 7 going to charity. The difference remains stark (more than a factor of five) even if we compare the "1off" results here with the "1Nepal" result from the equivalent charity-linked promotion from experiment 1 (temporally closer to the Nepal earthquakes). The findings are similar even if we consider the "Active Customers" sample instead.

\subsection{Promotion Take-up: Experiment 3}

One might wonder whether part of the differences between charity-linked and discount-based promotions above are driven by Nepal earthquake relief not being an important cause in the minds of Singapore-based customers. This consideration in part motivated experiment 3 , which relies instead on a local cause that people in Singapore did seem to care a lot about (at least as per local media coverage and a nationwide campaign in 2015): cancer-associated giving to a local charity called Singapore Cancer Society.

Further, experiment 3 has a broader range of conditions than experiment 2, with both charity-linked promotions and discount-based promotions considered for three different amounts: SGD 1, 5 and 10. This allows us to compute and compare the extent of diminishing returns with amount increases for the two kinds of promotions. As detailed in Table 1b, we employed stratified sampling wherein discount-based promotions and larger amounts were assigned smaller sample sizes during this random allocation.

The take-up rates by sample are reported in Table 1b, and shown graphically in Figure 1c. ${ }^{14}$ The take-up rate for a charity promotion for experiment 3 remains similar to that for a comparable amount in experiment 1 (and greater than in experiment 2). In line with Hypothesis 1, charity promotions take-up does increase as the amount increases. But we also see significant diminishing returns: across all samples, the take-up rates less than double when the charity amount goes up from SGD 1 to SGD 10.

\footnotetext{
13 This is also consistent with a finding reported by Madsen and Dodgers (2015) that, in a cross-sectional comparison of natural disaster relief initiatives across public companies, initiatives that were more prompt in addressing disaster-created needs received more stakeholder attention as inferred through greater media coverage. 14 The wording "up to 5 SGD" for "5off" and "up to 10 SGD" for "10off" makes it clear that - in line with similar promotions in the past - customers do not get "refunded" if their actual fare is smaller than the maximum discount allowed. In any case, such a scenario is not frequent: only 1 of the 468 " 5 off" cases had an estimated fare below SGD 5 and only 36 of the 311 "10off" cases below SGD 10. And even for these cases the gap was typically small.
} 
Not surprisingly, the take-up rates show diminishing returns for discount promotions as well. But, in line with Hypothesis 2, the take-up rate increase does not fall as rapidly as for charity promotions: customers seem more sensitive to the exact amount when it accrues to them in the form of a private discount rather than going to charity. Considering the "All Customers" sample, a tenfold increase in the charity amount (from SGD 1 in "1give" to SGD 10 in "10give") leads to the take-up rate becoming 1.96 times as much (up from $0.48 \%$ to $0.95 \%$ ), while doing the same for discount promotions (going from SGD 1 in "1off" to SGD 10 in "10off") leads to the take-up rate becoming 3.59 times as much (up from $3.47 \%$ to $12.44 \%$ ). These findings remain very similar if we instead analyse either the "Active Customers" sample (the two corresponding ratios being 1.87 and 3.26 for the charity and discount cases, respectively) or the "MultiPromo Customers" sample instead (the analogous ratios being 1.63 and 3.51, respectively).

\subsection{Regression Analysis for Promotion Take-Up}

We now employ a logistic regression framework to estimate the likelihood of customers taking up a promotion, helping us examine our first two hypotheses through statistical tests making more rigorous the informal comparisons above. This regression analysis is reported in Table 2, with the key independent variables being the indicator variables for different promotion codes within each experiment (represented using indicators for the respective promotion codes from Table $1 \mathrm{a}$ or $1 \mathrm{~b}$, with one of the group indicators for each experiment being omitted as reference). Taking experiment 3 as an illustration, and letting $y$ represent the dependent variable capturing whether a promotion is taken up, the likelihood of take-up of a promotion can be represented as the following estimation equation (with "1give" as the reference group):

$$
\operatorname{Pr}(y=1)=\Lambda\left(\beta_{0}+\beta_{5 \text { give }} i_{5 \text { give }}+\beta_{10 \text { give }} i_{10 \text { give }}+\beta_{\text {loff }} i_{1 \text { off }}+\beta_{5 o f f} i_{5 o f f}+\beta_{10 o f f} i_{10 o f f}+\beta_{W} W\right)
$$

Here, " $\Lambda(\beta X)$ " is the typical shorthand notation for the logistic function " $1 /(1+\exp (-\beta X))$ ", $W$ denotes the vector of other covariates, and $\beta$ is the vector of parameters to be estimated via regression analysis.

In interpreting the findings for experiment 1 in columns (1) and (2), it is useful to refer to Figure 1a. The omitted (reference) category in this model is the group receiving the " 1 Nepal" promotion. The take-up rates for "2sgd", "4sgd" and "Nepal5sgd" are positive and statistically significant relative to the reference, consistent with Hypothesis 1. In line with Figure 1a, the lack of significance for "Nepal3sgd", and the absence of an increase in going from " 2 sgd" to " 4 sgd", are anomalies in an otherwise monotonic trend. Cross-promotion comparison results for experiments 2 and 3 are similarly consistent with Figures $1 \mathrm{~b}$ and 1c respectively. Experiment 2 findings in columns (3) and (4) use "1sms" as the omitted (reference) category, and indicate that both "7sms" and "1off" have take-up rates that are larger in a statistically meaningful way - providing additional support for Hypothesis 1. Similarly, experiment 3 findings in 
columns (5) through (7), which are based on using "1give" as the omitted category, show that all other promotion codes within experiment 3 have significantly larger take-up rates than this reference, and that the magnitude of the coefficients increases with the monetary amount involved in all cases.

The findings on predicted take-up rates based on the regression analyses are almost identical to the corresponding findings based on the statistics in Tables 1a and 1b. For example, for the "All Customers" sample analysis in column (5) of Table 2 , the implied take-up rates are $0.48 \%, 0.82 \%$ and $0.95 \%$ for "1give", "5give" and "10give" respectively, and 3.46\%, 9.44\% and 12.34\% for "1off", "5off" and "10off" respectively. The take-up for charity-linked promotions is thus again an order of magnitude smaller than for discount-based promotions of comparable amounts. We again see diminishing returns in take-up rates for both kinds of promotions as the amount goes from SGD 1 to SGD 5 and ultimately to SGD 10 (the differences being statistically significant with $\mathrm{p}<0.01$ ). In line with Hypothesis 2, the sensitivity of takeup rates to the monetary amount is smaller for charity-linked than for discount-based promotions (a finding confirmed to hold statistically using a Wald test), again consistent with a view that charity take-up might in part be driven by a "warm glow" effect that is independent of the exact monetary amount.

Considering the included individual characteristics, customers making more bookings in the past four weeks (larger recent booking history), taking up a promotion in the past (past promotion indicator being one) and recently using an Apple device (apple device being one) were more likely to take up a promotion in all experiments. The findings are mixed (either insignificant or positive) for customer tenure.

\section{ANALYSIS OF LONGITUDINAL DEMAND PATTERNS}

Our main goal in this section is to analyse longitudinal taxi booking data for overall treatment effects from a given promotion for the entire group of customers that receive the promotion. However, analogous to additional analysis in Lewis and Reiley (2014) that considers just the subset of customers that decide to click on an online ad they were shown, we find it instructive to start by first considering the subset of customers that not only received a promotion but also chose to take up the promotion to make a booking.

\subsection{Longitudinal Patterns for Customers Taking up a Promotion}

\section{Selection Effects in Promotion Take-Up?}

Customers taking up promotions (Table A-5) systematically differed from the average customer profile (represented by the "No SMS" group in Table A-4): they had been more frequent users as per bookings they made in the 28 days prior to an experiment, had been a customer for the company for a longer tenure, were more likely to have taken up a past marketing promotion, and were more likely to be Apple users (the differences in means being statistically significant with $\mathrm{p}<0.01$ in all cases except for apple device 
in the case of the discount promotion in experiment 2). Relative to customers taking up discount-based promotions, those taking up charity-linked promotions were even more regular users pre-intervention (as indicated by an even larger mean for recent booking history in both experiment 2 and experiment 3 ).

Figures $2 \mathrm{a}, 2 \mathrm{~b}$ and $2 \mathrm{c}$ plot the daily taxi booking averages for customers taking up a promo code in the three respective experiments, averaged over four pre-intervention and post-intervention weeks to depict the temporal patterns despite high fluctuation from day to day (e.g., likely due to weekdays and weekends being systematically different). The $\mathrm{x}$-axis for each figure is labelled so that "Week 0" refers to the fiveday promotion period (as detailed in Table A-3). As a reference, the figures also plot the patterns for the corresponding time periods for the "No SMS" control groups (customers not sent any SMS at all). Corresponding summary statistics for daily taxi booking patterns, calculated as overall four-week preintervention and post-intervention averages, are presented in Tables $3 \mathrm{a}$ and $3 \mathrm{~b}$ for easy reference.

Interpreting graphically, three patterns stand out in examining Figures $2 a, 2 b$ and $2 c$ for selection effects associated with the profile of people taking up different promotions. First, people taking on promotions on average are regular users of the service to start with (i.e., their pre-intervention daily booking average is larger than for the "No SMS" group, a finding confirmed by t-tests). This is intriguing given that the intended goal of such marketing promotions is often to induce less active users to use service more.

Second, comparing within either kind of promotions (charity or discount) in an experiment, the average pre-intervention bookings per day are larger for customers taking up promotions involving smaller monetary amounts (e.g., in experiment 3, the pre-intervention average for "1give" is larger than for "5give", which in turn is greater than that for "10give"). Thus, customers taking on the promotion involving smaller amounts tend to be even more atypical in their pre-intervention booking frequency: as the amount involved increases, the take-up customers start to look more and more like the average customer in the population (represented by "No SMS" group). This pattern (verified through formal ttests) demonstrates that larger promotion amounts are needed to attract less regular customers.

The third selection-related pattern we find is that the pre-intervention averages are systematically larger for a charity promotion than a discount promotion of a comparable amount (e.g., in experiment 3, the preintervention average for "1give" is larger than for "1off", for "5give" is larger than for "5off", and for "10give" is larger than for "10ff"). This pattern (confirmed via formal t-tests) indicates that regular customers comprise a larger fraction of customers taking up charity promotions than discount promotions. One plausible explanation could be that regular customers identify better with the company, and are likely 
to take up charity-based promotions as they reaffirm this positive identification. However, we cannot fully disentangle this possibility from alternative explanations that might drive this finding. ${ }^{15}$

\section{A Possible Treatment Effect?}

Moving beyond investigation of selection effects in terms of pre-intervention patterns associated with subsequent promotion take up, longitudinal analysis of the take-up customer data for the duringpromotion and post-promotion periods is a natural precursor to a formal analysis of overall treatment effects. If there is indeed a significant overall treatment effect for a given promo code, it is likely to even more strongly manifest itself as a surge in taxi booking frequency specifically for the subset of customers taking up the promotion - analogous to an argument by Lewis and Reiley (2014) that a large component of their overall treatment effect would manifest as changes visible by considering the subset of customers that did choose to click on an online ad. However, given that a selection process (not fully observed) determines who takes up a promotion in the first place, this analysis is only indicative and we should be cautious in interpreting any patterns for take-up customers as causal estimates.

Looking at "week 0" in Figures 2a, 2b and 2c, we immediately notice a spike in the daily demand during the five-day promotion period. The existence of such a spike is not a surprise, as the sample by construction involves customers that had at least one booking during that period. What is more interesting is the exact size of this spike, which we can calculate by comparing the "pre" and "during" statistics for take-up customers in Tables $3 \mathrm{a}$ and $3 \mathrm{~b}$ (which can be further adjusted to get a "difference in differences" statistic accounting for temporal patterns captured as the difference in the "pre" and "during" statistics for the "No SMS" group, though that does not practically matter too much as that difference is small).

If the promotional rides were neither substitutes nor complements for non-promotional rides, we would expect this statistic regarding daily average rides to be exactly 0.2 (the one unit increase from the promotional ride divided over five days in the promotion period). On the other hand, if they came completely at the expense of non-promotional rides that would be taken anyway, the daily average should not have moved. The fact that the observed "difference in differences" indicator is much closer to 0.2 than to zero (always between 0.17 and 0.24 across experiments) indicates that the promotional rides do largely represent new demand. However, the fact that this increase does not significantly exceed 0.2 leads to a pessimistic nuance that the number of non-promotional bookings does not increase during the promotion

\footnotetext{
${ }^{15}$ For example, another possible reason could be that customers taking taxis more frequently are richer to start with and hence less sensitive to discounts. Yet another possibility (that a reviewer pointed out) is that people forget about charity promotions sooner than discount promotions (a conjecture supported by the fact that $25.3 \%$ of charity-linked redemptions but only $16.2 \%$ of discount-based redemptions in experiment 3 took place on day 1 of the promotion period), which means charity-linked promotions are redeemed more by customers making more frequent bookings.
} 
period. Carrying out a similar "difference in differences" analysis comparing the "pre" and "post" periods, we find little evidence of the booking frequency going up after the promotion period either. Overall, we therefore have little evidence so far consistent with a premise that promotion takeup is associated with increased customer purchase beyond the promotional booking itself. This non-finding holds for both charity-linked and discount-based promotions, so there is no support for an expectation that such an increase ought to be prominent at least for charity-linked promotions. It is worth reiterating that the above finding should not be taken as conclusive causal analysis. For example, even if we had found a positive effect, it could have been driven by customers who have anyway been increasing their taxi booking frequency being more likely to select into a promotion. Despite conditioning on the take-up by customers, however, there is at best weak support for Hypothesis 3 (the promotional booking itself possibly representing new demand, but with little further increase in demand) and no support for Hypothesis 4 (no evidence of a greater demand increase for charity promotions). Nevertheless, a rigorous test of our hypotheses requires estimating overall treatment effects, which we turn to next.

\subsection{Analysis of Overall Treatment Effects: Experiments 1 and 2}

Our regression approach for examining overall treatment effects allows for a possibility that not just the take-up customers but also other customers receiving a promo code (but not redeeming it) could be affected by a promotional message. ${ }^{16}$ We employ linear regressions with customer fixed effects (with standard errors clustered by customer), as these are easy to interpret and are well suited for difference-indifferences models with a large number of indicator variables (Angrist and Pischke, 2009). We also use a full set of indicators for the calendar date to control for daily fluctuations related to exogenous factors like weather or weekends as well as competitive factors like pricing or promotion decisions of competitors.

The first four columns in Table 4 report findings related to experiment 1 for our two samples ("All Customers" and "Active Customers") and two dependent variables ("Daily Bookings" and "Daily Fare"). The independent variable names starting with " $t_{-}$" are indicators that switch to one only for the indicated group and only during the "promotion window", and the independent variable names starting with " $p_{-}$" are indicators that similarly switch to one only for the indicated group and only for the 4-week "postpromotion window" immediately following the promotion window (see Table A-3). The last four columns in Table 4 report analogous analyses using variables and windows pertinent to experiment 2.

\footnotetext{
16 Tables 3a and 3b present average statistics for daily passenger rides in the "pre", "during" and "post" periods for "All Customers" as well as "Active Customers". Tables A-6a and A-6b present the same using daily passenger spending (in SGD) as the dependent variable. In the interest of brevity, we focus just on regression analysis here.
} 
In all eight models, the omitted (reference) category is the "No SMS" control group. We find that the regression estimates $\left(t_{-} N O C O D E\right.$ and $\left.p_{-} N O C O D E\right)$ for the "No Promocode" control group consistently lack statistical significance, indicating that any other significant findings can be interpreted as relating to actual receiving a promo code SMS and not just receiving a generic SMS from the company.

Looking at the estimated coefficients for the promotion period effects (variable names starting with " $\left.t_{-} "\right)$, we do not find statistically significant effects for any of the treatment groups in any of the eight models. Turning to the estimated coefficients for the post-promotion period effects (variable names starting with " $p_{-}$”), we do not find any statistically significant coefficient estimate that has a positive sign. All postestimates for seven of the eight promotions are statistically insignificant, with the remaining promotion group ("2sgd") showing a mix of negative and insignificant effects. To summarize, the first two experiments provide no support to either Hypothesis 3 (that charity promotions boost overall demand) or Hypothesis 4 (that charity promotions do so more effectively than discount promotions). ${ }^{17}$

\subsection{Analysis of Overall Treatment Effects: Experiment 3}

In the first four columns of Table 5, we report longitudinal analyses for experiment 3 that mimics the corresponding analyses shown in Table 4 for the first two experiments. Considering the three charity promotions first, we find no overall treatment effects during the promotion period (looking at t_5give and t_10give) irrespective of whether we use Daily Bookings or Daily Fare as the dependent variable. Very similar non-finding holds even when examining the treatment effects for the postpromotion period (looking at $p \_$lgive, $p \_$5give and $p \_$10give), except for the estimate for $p \_5 g i v e$ being marginally significant ( $\mathrm{p}=0.10$ ) when using Daily Booking (but not Daily Fare) as the dependent variable.

We now turn to the results for three discount promotions, still focusing on the first four columns of Table 5. Unlike for charity promotions, we now do consistently find treatment effects during the promotion period (looking at $t \_$loff, $t \_5 o f f$ and $t \_10 o f f$ ), irrespective of whether we use Daily Bookings or Daily Fare as the dependent variable. However, the treatment effects for the post-promotion period (looking at p_loff, $p \_5 o f f$ and $\left.p \_10 o f f\right)$ are weaker: the estimates are statistically insignificant except for being marginally significant $\left(\mathrm{p}=0.10\right.$ ) in some cases for $p \_5 o f f$ (for Daily Booking in both samples and Daily Fare in the "All Customers" sample) and p_loff (only for Daily Fare in the "All Customers" sample).

\footnotetext{
${ }^{17}$ Given the low take-up rates for charity promotions, finding an overall treatment effect is hard if the promotion does not positively impact people not taking up the promotions. However, recall that the "difference in difference" summary statistic evidence was weak even for the take-up customers. Consistent with that analysis, regression analysis (not reported here) using just the take-up customer sample also finds the " $t_{-}$" coefficient estimates to be close to 0.2 , again indicative of the promotional booking itself representing new demand but not leading to any additional demand in the promotion window. Further, almost all the " $p_{-}$" coefficients remained statistically insignificant in that analysis. In other words, even if the promotional ride itself does represent new demand, it brings no multiplier effect in terms of increased non-promotional bookings even for the customers taking up a promotion.
} 
To generate further insight into the seemingly strong treatment effects for discount promotions during the promotion period, we carried out additional analysis (not reported in the table) using another dependent variable that only considers non-promotional bookings. In this case, the estimates for all three treatment effects ( $t$ _lgive, $t$ 5give and $t \_$10give) turn negative and significant (for the "All Customers" sample as well as "Active Customers" sample). This is indicative that the overall findings for the promotion period are driven just by promotion take-up itself (which is much greater for discount promotions than charity promotions), without evidence of a positive effect in terms of increasing non-promotional bookings.

In the last two columns of Table 5, we replicate the above analysis for the "Multi-Promo Customers" sample. Recall that, within each treatment group for experiment 3, a subset of customers had received a promo code in an earlier experiment. In the analysis above, we just calculated average treatment effects for experiment 3 and ignored this distinction, which is acceptable for research design as the customers receiving a message in an earlier experiment are randomly distributed across conditions. Nevertheless, specifically focusing on "Multi-Promo Customers" allows us to dig into the possibility that the treatment effects might be different for customers receiving more than one promotion.

For interpreting the findings for "Multi-Promo Customers", recall that the treatment groups in this sample include experiment 3 customers that had already received a charity promotion SMS in either experiment 1 or 2, while the control group comprises of customers that did not receive an SMS in any of the three experiments (see Table A-2). Four observations are worth making. First, there is still no evidence of treatment effects for charity promotions (looking at $t$ _lgive, $t$ _5give and $t$ _logive) during the promotion period. Second, we again find no treatment effect for charity promotions after the promotion period as far as Daily Bookings are concerned, though we now see marginally significant effects $(\mathrm{p}=0.10)$ for Daily

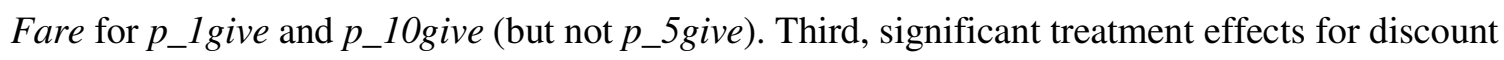
promotions during the promotion period still exist (except for $t_{-}$loff for Daily Bookings), though there is little evidence of these effects being any larger than for the corresponding estimates in the full "All Customers" sample (first two columns). Finally, the treatment effects for the discount promotions for the post-promotion period for $p \_1 o f f$ and $p \_5 o f f$ are again mixed (holding somewhat for Daily Fare but not at all for Daily Bookings), and for $p_{-}$10off once again consistently insignificant across both columns.

It is worth summarizing the above findings, especially considering our starting hypotheses related to charity-linked promotions. As in the prior experiments, there is little evidence to support a view that charity promotions increase overall demand (Hypothesis 3), or that they are more effective at doing so than discount promotions (Hypothesis 4). If anything, the treatment effects appear to be stronger for discount promotions at least during the promotion period. In any case, most of even the statistically 
significant effects seem either economically small or short-lived: there is relatively limited evidence to support our hypotheses regarding long-term effects of charity-linked promotions.

\section{DISCUSSION AND CONCLUSION}

\subsection{Summary}

Rigorous evidence on selection and treatment effects associated with philanthropic promotions remains scarce, especially in the empirical context of online marketplaces spending large amounts of invested funds on such promotions. Our research design combines the general benefits of an experimental approach with the specific benefits of carrying these out as field experiments in the context of a real firm. By studying charity-linked promotions for varying amounts and different causes, and also including analogous discount-based promotions in our experiments, we have been able to conduct a like-for-like comparison of take-up rates and longitudinal purchase patterns across a range of promotions.

Take-up rates for charity-linked promotions were much smaller than for discount-based promotions of comparable amounts. Interesting implications arise from our finding that take-up rates for charity-linked promotions were also not as sensitive to the exact amount. For a profit-maximizing firm, this suggests that the optimal approach - even assuming it makes sense for it to employ a philanthropic campaign based on promotions like the ones we examine - might be to keep the donation amounts small.

Intriguingly, we find little evidence of a boost in long-term demand from our promotions. As our promotions involved between SGD 1 and SGD 10, this cost exceeds the flat fee the company earns per booking (even for the cheapest promotion, and even ignoring the additional cost of messaging and administration). Thus, our finding that a promotion does not have any spill-over benefit beyond the promotional booking itself raises concerns regarding its "business case". While the specific economics might differ across settings (e.g., if a company earned a percentage rather than a flat fees), our findings provide a reason to be sceptic about the "more is better" mindset to promotions often seen in practice.

\subsection{Limitations and Future Research}

While carrying out field experiments makes the study rigorous and realistic, it does face concerns about external generalizability. Some of such effects might be firm-specific, e.g., as customers identify with firms differently or perceive them as being different in authenticity (Cuypers, Koh and Wang, 2016; Patten, 2008; Servaes and Tamayo 2013). Caution should therefore be exercised in extrapolating across firms that differ in their prosocial reputation or positioning (Brown and Dacin, 1997; Du, Bhattacharya and Sen, 2011; Luo and Bhattacharya, 2006). Our findings may also be specific to the sector or the 
competitive landscape involved. For example, the nature of the product - whether it is a basic product versus one with premium or luxury positioning - is known to shape such effects (Strahilevitz, 1999; Strahilevitz and Myers, 1998). The results might also be unique to our specific geography, although bringing a dataset from outside the U.S. (specifically from Asia) is also a unique empirical contribution.

Our study focuses just on existing customers, and promotions sent to new customers might have different effects. We can also not rule out the possibility that framing the messages differently or using other charitable causes might produce different results. Our experiments involve messages received and responded to privately, not allowing for effects that could have been facilitated by social pressures (Ariely, Bracha and Meier, 2009; Bénabou and Tirole, 2006). Further, following Singh (2005), who examines knowledge diffusion through geographically localized interpersonal networks, it would be of interest to use location data on customers to investigate possible diffusion effects in promotion take-up.

One reason that the long-term treatment effect for our charity-linked promotions is generally insignificant might be that a single SMS promotion is a relatively weak intervention (with low associated take-up rates). ${ }^{18}$ Although our results are robust to analysing a sample where the treatment involved two SMS promotions instead of one, it is plausible that a larger threshold of repetition is needed for effectiveness. In fact, a budget used for running a single discount-based promotion just once could suffice for sending a comparable population multiple charity-linked promotions (as they have lower take-up). It is also likely that some of the effects differ across customers with different sensitivity to pro-social campaigns (Hainmueller and Hiscox, 2012a). Another extension to this study would therefore be to ask what kind of targeting might help get more "bang for the buck" (Acquisti and Varian, 2005; Barone and Roy, 2010).

We close with three broader caveats. First, we have considered only a specific kind of philanthropic campaigns: those that involves charity-linked promotions. Second, we have not considered industry and competitive dynamics, such as market-creation versus market-stealing effects or promotions and competitor response (e.g., through promotions of their own). Third, we have only considered customerrelated outcomes, whereas a "business case" for social engagement might also involve mechanisms operating through a more diverse set of a firm's stakeholders (Besley and Ghatak, 2005; Bode, Singh and Rogan, 2015; Henisz, Dorobantu and Nartey, 2014; Muller and Kraussl, 2011). However, we hope that our use of rigorous field experiments to examine issues related to corporate philanthropy and CSR will encourage more such research on these topics in management research.

\footnotetext{
${ }^{18}$ Nevertheless, it is worth noting that our study is not the first to employ simple single-message interventions: in experiments carried out in other contexts, single messages of comparable simplicity as ours have sometimes been found to produce significant effects (Grant and Hoffman, 2011).
} 


\section{REFERENCES}

Acquisti A, Varian HR (2005) Conditioning prices on purchase history. Marketing Science 24(3): 367-81.

Advertising Age (2003) Cause marketing: After two decades of growth, the \$1 billion spending mark is in sight. July 28: 2.

Ailwadi K, Harlam B, Cesar J, Trounce D (2006) Promotion profitability for a retailer: The role of promotion, brand, category, and store characteristics. Journal of Marketing Research 43: 518-535.

Andreoni, J (1990) Impure altruism and donations to public goods: A theory of warm-glow giving. Economic Journal 100 (June): 464-77.

Andreoni J, Payne AA (2013) Charitable giving. Chapter 1 in Handbook of Public Economics, Vol 5, (Amsterdam: North Holland), A. Auerbach, R. Chetty, M. Feldstein, E. Saez, editors, 1-50.

Angrist JD, Pischke JS (2009) Mostly Harmless Econometrics: An Empiricist's Companion. Princeton University Press.

Anik L, Norton MI, Ariely D (2014) Contingent match incentives increase donations. Journal of Marketing Research LI: 790-801.

Aribarg A, Arora N (2008) Brand portfolio promotions. Journal of Marketing Research 45: 391-402.

Ariely D, Bracha A, Meier S (2009) Doing good or doing well? Image motivation and monetary incentives in behaving prosocially. American Economic Review 99(1): 544-555.

Arnett DB, German SD, Hunt SD (2003) The identity salience model of relationship marketing success: The case of non-profit marketing. Journal of Marketing 67(2): 89-105.

Arora N, Henderson T (2007) Embedded premium promotion: Why it works and how to make it more effective. Marketing Science 26: 514-531.

Barone MJ, Roy T (2010) Does exclusivity always pay off? Exclusive price promotions and consumer response. Journal of Marketing 74(2): 121-132.

Bartling B, Weber RA, Yao L (2015) Do markets erode corporate social responsibility? Quarterly Journal of Economics 130(1): 219-266.

Bénabou R, Tirole J (2006) Incentives and prosocial behavior. American Economic Review 96(5): 16521678.

Besley T, Ghatak M (2005) Competition and incentives with motivated agents. American Economic Review 95(3): 616-636.

Blattberg RC, Neslin SA (1990) Sales Promotions: Concepts, Methods and Strategies. Englewood Cliffs, NJ: Prentice Hall.

Bode C, Singh J, Rogan M (2015) Corporate social initiatives and employee retention. Organization Science 26(6): 1702-1720.

Bronn PS, Vrioni AB (2001) Corporate social responsibility and cause-related marketing: An overview. International Journal of Advertising 20: 207-222.

Brown TJ, Dacin PA (1997) The company and the product: corporate associations and consumer product responses. Journal of Marketing 61(1): 68-84.

Burbano VC (2016) Social responsibility messages and worker wage requirements: Field experimental evidence from online labor marketplaces. Organization Science 27(4): 1010-1028.

Carson RT (2012) Contingent valuation: A practical alternative when prices aren't available. Journal of Economic Perspectives 26(4): 27-42.

Charness G, Fehr E. (2015) From the lab to the real world. Science 350: 512-513.

Charness G, Gneezy U, Kuhn M (2013) Experimental methods: Extra-laboratory experiments - extending the reach of experimental economics. Journal of Economic Behavior \& Organization, 91: 93-100 
Chatterji AK, Findley MG, Jensen NM, Meier S, Nieldson D (2016) Field experiments in strategy research. Strategic Management Journal 37(1): 116-132.

Cone (2015) Cone Communications/Ebiquity Global CSR Study. Cone Communications. Downloaded http://www.conecomm.com/2015-global-csr-study on March 3, 2016.

Cuypers IRP, Koh PS, Wang H (2016) Sincerity in corporate philanthropy, stakeholder perceptions and firm value. Organization Science, forthcoming.

Desvousges WH, Johnson FR, Dunford RW, Hudson SP, Wilson KN, Boyle KJ (1993). Measuring resource damages with contingent valuation: Tests of validity and reliability. In J. Hausamn (Ed.), Contingent valuation: A critical assessment (pp. 91-164). Amsterdam: North-Holland.

Devinney, TM, Auger P, Eckhardt GM (2010) The Myth of the Ethical Consumer. Cambridge: Cambridge University Press.

Du S, Bhattacharya CB, Sen S (2011) Corporate social responsibility and competitive advantage: Overcoming the trust barrier. Management Science 57:1528-1545.

Eccles RG, Ioannou I, Serafeim G (2014) The impact of corporate sustainability on organizational processes and performance. Management Science 60 (11): 2835-2857.

Elfenbein DW, Fisman R, McManus B (2012) Charity as a substitute for reputation: Evidence from an online marketplace. Review of Economic Studies 79:1441-1468.

Elfenbein DW, McManus B (2010) A greater price for a greater good? Evidence that consumers pay more for charity-linked products. American Economic Journal: Economic Policy 2:28-60.

Erat S, Gneezy U (2011) White lies. Management Science 58 (4): 723-733.

Goldstein NJ, Cialdini RB, Griskevicius V (2008) A room with a viewpoint: Using social norms to motivate environmental conservation in hotels. Journal of Consumer Research 35(3): 472-482.

Gneezy A, Gneezy U, Nelson LD, Brown A (2010) Shared social responsibility: A field experiment in pay-what-you-want pricing and charitable giving. Science 329(5989): 325-327.

Gneezy U, Imas A, Madarasz K (2014) Conscience accounting: Emotion dynamics and social behavior. Management Science 60(11): 2645-2658.

Grant AM, Hofmann DA (2011) Motivating hand hygiene among health care professionals by focusing on patients. Psychology Science 22(12): 1494-1499.

Hainmueller J, Hiscox MJ (2012a) Buying green? Field experimental tests of consumer support for environmentalism. Working Paper.

Hainmueller J, Hiscox MJ (2012b) The socially conscious consumer? Field experimental tests of consumer support for fair labor standards. Working Paper.

Hainmueller, J, Hiscox MJ, Sequeira S (2015) Consumer demand for Fair Trade: Evidence from a multistore field experiment. Review of Economics and Statistics 97(2): 242-256.

Harrison GW, List JA (2004) Field experiments. Journal of Economic Literature 42(4): 1009-1055.

Henderson T, Arora N (2010) Promoting brands across categories with a social cause: Implementing effective embedded premium programs. Journal of Marketing 75: 41-60.

Henisz W, Dorobantu S, Nartey L (2014) Spinning gold: The financial returns to external stakeholder engagement. Strategic Management Journal 35:1727-1748.

Hirshleifer D, Jian M, Zhang H (2016) Superstition and financial decision making. Management Science, forthcoming.

Hiscox MJ, Broukhim M, Litwin C (2011) Consumer demand for fair trade: New evidence from a field experiment using eBay auctions of fresh roasted coffee. Working Paper. 
Hoeffler S, Keller KL (2002). Building brand equity through corporate societal marketing. Journal of Public Policy \& Marketing 21(1): 78-89

Hossain T, Li KK (2014) Crowding out in the labor market: A prosocial setting is necessary. Management Science 60(5): 1148-1160.

Hsee CK, Rottenstreich Y (2004) Music, pandas, and muggers: on the affective psychology of value. Journal of Experimental Psychology: General 133(1):23-30.

Hull CE, Rothenberg S (2008) Firm performance: The interactions of corporate social performance with innovation and industry differentiation. Strategic Management Journal 29: 781-789.

IEG (2015) Sponsorship spending report. Downloaded on March 2, 2016 from http://www.sponsorship.com/IEG/files/4e/4e525456-b2b1-4049-bd51-03d9c35ac507.pdf.

Imas A (2014) Working for the warm glow: On the benefits and limits of prosocial incentives. Journal of Public Economics 114: 14-18.

Kahneman D, Ritov I, Schkade D (1999) Economic preferences or attitude expressions? An analysis of dollar responses to public issues. Journal of Risk and Uncertainty 19(1): 203-235.

Karlan D, List JA (2007) Does price matter in charitable giving? Evidence from a large-scale natural field experiment. American Economic Review 97(5): 1774-1793.

Karlan D, Wood DH (2016) The effect of effectiveness: Donor response to aid effectiveness in a direct mail fundraising experiment. Journal of Behavioral and Experimental Economics, forthcoming.

Krishna A, Rajan U (2009) Cause marketing: Spillover effects of cause-related products in a product portfolio. Management Science 55(9): 1469-1485.

Lazear EP, Malmendier U, Weber RA (2012) Sorting in experiments with application to social preferences. American Economic Journal: Applied Economics 4(1): 136-163.

Lev B, Petrovits C, Radhakrishnan S (2010) Is doing good good for you? How corporate charitable contributions enhance revenue growth. Strategic Management Journal 31(2): 182-200.

Levitt S, List J (2007) What do laboratory experiments measuring social preferences tell us about the real world? Journal of Economic Perspectives 21:153-174.

Lewis RA, Reiley DH (2014) Online ads and offline sales: Measuring the effects of online advertising via a controlled experiment on Yahoo! Quantitative Marketing and Economics 12(3): 235-266.

Lichtenstein DR, Drumwright ME, Braig BM (2004) The effect of corporate social responsibility on customer donations to corporate-supported nonprofits. Journal of Marketing 68: 16-32.

Luo X, Bhattacharya CB (2006) Corporate social responsibility, customer satisfaction, and market value. Journal of Marketing 70(4): 1-18.

MSLGROUP (2014) The future of business citizenship. MSLGROUP. Downloaded on March 2, 2016 from http://www.mslgroup.com/insights/2014/the-future-of-business-citizenship.

Madsen PM, Rodgers ZJ (2015) Looking good by doing good: The antecedents and consequences of stakeholder attention to corporate disaster relief. Strategic Management Journal 36: 776-794.

Margolis JD, Elfenbein HA, Walsh JP (2009) Does it pay to be good...and does it matter? A metaanalysis of the relationship between corporate social and financial performance. Working Paper.

Mazar N, Zhong CB (2010) Do green products make us better people? Psychological Science 21: 494-98.

Meier S (2007) A survey of economic theories and field evidence on pro-social behavior. In Economics and Psychology: A Promising New Cross-Disciplinary Field, ed. BS Frey and A Stutzer, 51-88.

Muller A, Kräussl R (2011) Doing good deeds in times of need: A strategic perspective on corporate disaster donations. Strategic Management Journal 32: 911-929. 
Newman GE, Gorlin M, Dhar R (2014) When going green backfires: How firm intentions shape the evaluation of socially beneficial product enhancements. Journal of Consumer Research 41(3): 823839.

Null C (2011). Warm glow, information, and inefficient charitable giving. Journal of Public Economics 95(5): 455-465.

Patten D (2008) Does the market value corporate philanthropy? Evidence from the response to the 2004 tsunami relief effort. Journal of Business Ethics 81(3): 599-607.

Porter ME, Kramer MR (2002) The competitive advantage of corporate philanthropy. Harvard Business Review 80(12): 56-68.

Porter ME, Kramer MR (2011) Creating shared value. Harvard Business Review: 62-77.

Ryzhov IO, Han B, Bradic J (2015) Cultivating disaster donors using data analytics. Management Science.

Sen S, Bhattacharya CB (2001) Does doing good always lead to doing better? Consumer reactions to corporate social responsibility. Journal of Marketing Research 38(2): 225-243.

Servaes H, Tamayo A (2013) The impact of corporate social responsibility on firm value: The role of customer awareness. Management Science 59:1045-1061.

Shang J, Reed A, Croson R (2008) Identity congruency effects on donations. Journal of Marketing Research 45(3): 351-361.

Sheikh SR, Beise-Zee R (2011) Corporate social responsibility or cause-related marketing? The role of cause specificity of CSR. Journal of Marketing Research 28(1): 27-39.

Singh J (2015) Collaborative networks as determinants of knowledge diffusion patterns. Management Science 51(5): 756-770.

Solomon B (2016). Leaked: Uber's financials show huge growth, even bigger losses. Accessed at http://www.forbes.com/sites/briansolomon/2016/01/12/leaked-ubers-financials-show-huge-growtheven-bigger-losses on January 21, 2016.

Strahilevitz MA (1999) The effects of product type and donation magnitude on willingness to pay more for a charity-linked brand. Journal of Consumer Psychology 8(3): 215-241.

Strahilevitz MA, Myers JG (1998) Donations to charity as purchase incentives: How well they work may depend on what you are trying to sell. Journal of Consumer Research 24: 434-446.

Tonin M, Vlassopoulos M (2010) Disentangling the sources of pro-socially motivated effort: A field experiment. Journal of Public Economics 94(11-12): 1086-1092.

Varadarajan PR, Menon A (1988) Cause-related marketing: A co-alignment of marketing strategy and corporate strategy and corporate philanthropy. Journal of Marketing 52(3): 58-74.

White K, Peloza J (2009) Self-benefit versus other-benefit marketing appeals: Their effectiveness in generating charitable support. Journal of Marketing 73(4): 109-124.

Winterich KP, Barone MJ (2011) Warm glow or cold, hard cash? Social identity effects on consumer choice for donations versus discount promotions. Journal of Marketing Research XLVIII: 855-86 
Table 1a. Customer groups, promotion codes and take-up rates: Experiments 1 and 2

\begin{tabular}{|c|c|c|c|c|c|c|c|c|c|c|}
\hline & \multicolumn{5}{|c|}{ EXPERIMENT \#1 } & \multicolumn{5}{|c|}{ EXPERIMENT \#2 } \\
\hline & \multirow[b]{2}{*}{ Promocode } & \multicolumn{2}{|c|}{ All Customers } & \multicolumn{2}{|c|}{ Active Customers } & \multirow[b]{2}{*}{ Promocode } & \multicolumn{2}{|c|}{ All Customers } & \multicolumn{2}{|c|}{ Active Customers } \\
\hline & & $N$ & Take-up & $N$ & Take-up & & $N$ & Take-up & $N$ & Take-up \\
\hline \multicolumn{11}{|l|}{ Charity promotion: } \\
\hline$S G D 1$ to Nepal relief & $1 \mathrm{Nepal}$ & 19,108 & $92(0.48 \%)$ & 11,739 & $88(0.75 \%)$ & $1 s m s$ & 28,000 & $62(0.22 \%)$ & 16,610 & $58(0.35 \%)$ \\
\hline SGD 2 to Nepal relief & $2 s g d$ & 19,108 & $129(0.68 \%)$ & 11,706 & $119(1.02 \%)$ & & & & & \\
\hline SGD 3 to Nepal relief & Nepal3sgd & 19,108 & $98(0.51 \%)$ & 11,615 & $89(0.77 \%)$ & & & & & \\
\hline SGD 4 to Nepal relief & $4 s g d$ & 19,108 & $128(0.67 \%)$ & 11,792 & $119(1.01 \%)$ & & & & & \\
\hline SGD 5 to Nepal relief & Nepal5sgd & 19,108 & $166(0.87 \%)$ & 11,595 & $151(1.30 \%)$ & & & & & \\
\hline SGD 7 to Nepal relief & & & & & & $7 s m s$ & 28,000 & $126(0.45 \%)$ & 16,639 & $115(0.69 \%)$ \\
\hline \multicolumn{11}{|l|}{ Discount promotion: } \\
\hline SGD 1 discount & & & & & & $10 f f$ & 8,000 & $204(2.55 \%)$ & 4,729 & $180(3.81 \%)$ \\
\hline Subtotal for promotions & & 95,540 & $613(0.64 \%)$ & 58,447 & $566(0.97 \%)$ & & 64,000 & $392(0.61 \%)$ & 37,978 & $353(0.93 \%)$ \\
\hline \multicolumn{11}{|l|}{ No promotion (controls): } \\
\hline No promocode in SMS & NONE & 19,107 & & 11,783 & & NONE & 28,000 & & 16,613 & \\
\hline NoSMS & NONE & 53,857 & & 32,988 & & NONE & 53,857 & & 31,848 & \\
\hline Total sample size & & 168,504 & & 103,218 & & & 145,857 & & 86,439 & \\
\hline
\end{tabular}

Table 1b. Customer groups, promotion codes and take-up rates: Experiment 3

\begin{tabular}{|c|c|c|c|c|c|c|c|}
\hline & \multicolumn{7}{|c|}{ EXPERIMENT \#3 } \\
\hline & \multirow[b]{2}{*}{ Promocode } & \multicolumn{2}{|c|}{ All Customers } & \multicolumn{2}{|c|}{ Active Customers } & \multicolumn{2}{|c|}{ Multi-Promo Customers } \\
\hline & & $N$ & Take-up & $N$ & Take-up & $N$ & Take-up \\
\hline \multicolumn{8}{|l|}{ Charity promotion: } \\
\hline SGD 1 to Singapore Cancer Society & Igive & 50,000 & $242(0.48 \%)$ & 24,746 & $224(0.91 \%)$ & 29,060 & $152(0.52 \%)$ \\
\hline SGD 5 to Singapore Cancer Society & Sgive & 50,000 & $406(0.81 \%)$ & 24,473 & $367(1.50 \%)$ & 29,060 & $228(0.78 \%)$ \\
\hline SGD 10 to Singapore Cancer Society & 10give & 20,000 & $190(0.95 \%)$ & 9,923 & $168(1.69 \%)$ & 11,624 & $99(0.85 \%)$ \\
\hline \multicolumn{8}{|l|}{ Discount promotion: } \\
\hline SGD 1 discount & $10 f f$ & 50,000 & $1,734(3.47 \%)$ & 24,656 & $1,582(6.42 \%)$ & 29,060 & $1,026(3.53 \%)$ \\
\hline$S G D 5$ discount & $50 f f$ & 5,000 & $468(9.36 \%)$ & 2,457 & $403(16.40 \%)$ & 2,906 & $260(8.95 \%)$ \\
\hline SGD 10 discount & $100 \mathrm{ff}$ & 2,500 & $311(12.44 \%)$ & 1,238 & $259(20.92 \%)$ & 1,453 & $180(12.39 \%)$ \\
\hline Subtotal for promotions & & 177,500 & $3,351(1.89 \%)$ & 87,493 & $3,003(3.43 \%)$ & 103,163 & $1,945(1.89 \%)$ \\
\hline \multicolumn{8}{|l|}{ No promotion (controls): } \\
\hline No promocode in SMS & NONE & 50,000 & & 24,564 & & 10,360 & \\
\hline NoSMS & NONE & 33,004 & & 16,236 & & 6,719 & \\
\hline Total sample size & & 260,504 & & 128,293 & & 120,242 & \\
\hline
\end{tabular}


Table 2. Logistic regression analysis of promotion take-up behavior

\begin{tabular}{|c|c|c|c|c|c|c|c|}
\hline \multirow{3}{*}{ Customer Sample: } & \multicolumn{2}{|c|}{ EXPERIMENT \#1 } & \multicolumn{2}{|c|}{ EXPERIMENT \#2 } & \multicolumn{3}{|c|}{ EXPERIMENT \#3 } \\
\hline & $\begin{array}{c}\text { All Customers } \\
\text { (excluding controls) }\end{array}$ & $\begin{array}{c}\text { Active customers } \\
\text { (excluding controls) }\end{array}$ & $\begin{array}{c}\text { All Customers } \\
\text { (excluding controls) }\end{array}$ & $\begin{array}{l}\text { Active customers } \\
\text { (excluding controls) }\end{array}$ & $\begin{array}{c}\text { All Customers } \\
\text { (excluding controls) }\end{array}$ & $\begin{array}{l}\text { Active customers } \\
\text { (excluding controls) }\end{array}$ & $\begin{array}{l}\text { Multi-Promo Customers } \\
\text { (excluding controls) }\end{array}$ \\
\hline & (1) & (2) & (3) & (4) & (5) & (6) & (7) \\
\hline $\begin{array}{l}\text { Experiment \#1 Subgroup Indicator: } \\
\text { i_1Nepal (SGD } 1 \text { to Nepal relief) }\end{array}$ & [Omitted] & [Omitted] & & & & & \\
\hline i_2sgd (SGD 2 to Nepal relief) & $\begin{array}{l}0.3350^{*} \\
(0.1378)\end{array}$ & $\begin{array}{l}0.3035^{*} \\
(0.1417)\end{array}$ & & & & & \\
\hline i_Nepal3sgd (SGD 3 to Nepal relief) & $\begin{array}{c}0.0724 \\
(0.1461)\end{array}$ & $\begin{array}{c}0.0233 \\
(0.1513)\end{array}$ & & & & & \\
\hline i_Nepal5sgd (SGD 5 to Nepal relief) & $\begin{array}{l}0.6092^{* *} \\
(0.1310)\end{array}$ & $\begin{array}{l}0.5645^{* *} \\
(0.1351)\end{array}$ & & & & & \\
\hline $\begin{array}{l}\text { Experiment \#2 Subgroup Indicator: } \\
\text { i_1sms (SGD } 1 \text { to Nepal relief) }\end{array}$ & & & [Omitted] & [Omitted] & & & \\
\hline i_7sms (SGD 7 to Nepal relief) & & & $\begin{array}{l}0.7423^{* *} \\
(0.1563)\end{array}$ & $\begin{array}{l}0.7049^{* *} \\
(0.1618)\end{array}$ & & & \\
\hline i_1off (SGD 1 discount) & & & $\begin{array}{l}2.5478^{* *} \\
(0.1472)\end{array}$ & $\begin{array}{l}2.4783^{* *} \\
(0.1529)\end{array}$ & & & \\
\hline i_sgive (SGD 5 to Singapore Cancer Society) & & & & & $\begin{array}{l}0.5717^{* *} \\
(0.0830)\end{array}$ & $\begin{array}{l}0.5437^{* *} \\
(0.0861)\end{array}$ & $\begin{array}{l}0.4519^{* *} \\
(0.1072)\end{array}$ \\
\hline i_10give (SGD 10 to Singapore Cancer Society) & & & & & $\begin{array}{l}0.7208^{* *} \\
(0.0992)\end{array}$ & $\begin{array}{l}0.6545^{* *} \\
(0.1038)\end{array}$ & $\begin{array}{l}0.5321^{* *} \\
(0.1319)\end{array}$ \\
\hline i_ 1off (SGD 1 discount) & & & & & $\begin{array}{l}2.1162^{* *} \\
(0.0706)\end{array}$ & $\begin{array}{l}2.0904^{* *} \\
(0.0730)\end{array}$ & $\begin{array}{l}2.0457^{* *} \\
(0.0897)\end{array}$ \\
\hline i_5off (SGD 5 discount) & & & & & $\begin{array}{l}3.2887^{* *} \\
(0.0840)\end{array}$ & $\begin{array}{l}3.2389^{* *} \\
(0.0890)\end{array}$ & $\begin{array}{l}3.1553^{* *} \\
(0.1086)\end{array}$ \\
\hline i_10off (SGD 10 discount) & & & & & $\begin{array}{l}3.6278^{* *} \\
(0.0926)\end{array}$ & $\begin{array}{l}3.5368^{* *} \\
(0.1002)\end{array}$ & $\begin{array}{l}3.5560^{* *} \\
(0.1193)\end{array}$ \\
\hline recent booking history & $\begin{array}{l}0.0540^{* *} \\
(0.0032)\end{array}$ & $\begin{array}{l}0.0409^{* *} \\
(0.0035)\end{array}$ & $\begin{array}{l}0.0520^{* *} \\
(0.0044)\end{array}$ & $\begin{array}{l}0.0373^{* *} \\
(0.0050)\end{array}$ & $\begin{array}{l}0.0612^{* *} \\
(0.0015)\end{array}$ & $\begin{array}{l}0.0440^{* *} \\
(0.0017)\end{array}$ & $\begin{array}{l}0.0614^{* *} \\
(0.0020)\end{array}$ \\
\hline customer tenure & $\begin{array}{c}0.1316 \\
(0.1067)\end{array}$ & $\begin{array}{l}0.0850 \\
(0.1079)\end{array}$ & $\begin{array}{l}0.4705^{* *} \\
(0.1308)\end{array}$ & $\begin{array}{l}0.4097^{* *} \\
(0.1356)\end{array}$ & $\begin{array}{l}0.1740^{* *} \\
(0.0476)\end{array}$ & $\begin{array}{c}0.0202 \\
(0.0508)\end{array}$ & $\begin{array}{l}0.1478^{*} \\
(0.0624)\end{array}$ \\
\hline past promotion takeup & $\begin{array}{l}0.7436^{* *} \\
(0.1118)\end{array}$ & $\begin{array}{l}0.6817^{* *} \\
(0.1127)\end{array}$ & $\begin{array}{l}0.9779^{* *} \\
(0.1295)\end{array}$ & $\begin{array}{l}0.8839 * * \\
(0.1318)\end{array}$ & $\begin{array}{l}1.4159^{* *} \\
(0.0380)\end{array}$ & $\begin{array}{l}1.1838^{* *} \\
(0.0404)\end{array}$ & $\begin{array}{l}1.4204^{* *} \\
(0.0498)\end{array}$ \\
\hline apple device & $\begin{array}{l}0.3423^{* *} \\
(0.0884)\end{array}$ & $\begin{array}{l}0.2841^{* *} \\
(0.0920)\end{array}$ & $\begin{array}{l}0.3955^{* *} \\
(0.1112)\end{array}$ & $\begin{array}{l}0.3327^{* *} \\
(0.1177)\end{array}$ & $\begin{array}{l}0.2360^{* *} \\
(0.0390)\end{array}$ & $\begin{array}{l}0.1594^{* *} \\
(0.0417)\end{array}$ & $\begin{array}{l}0.2333^{* *} \\
(0.0512)\end{array}$ \\
\hline Constant & $\begin{array}{l}-5.9821^{* *} \\
(0.1351)\end{array}$ & $\begin{array}{l}-5.4844^{* *} \\
(0.1394)\end{array}$ & $\begin{array}{c}-7.0690^{* *} \\
(0.1726)\end{array}$ & $\begin{array}{c}-6.5372^{* *} \\
(0.1822)\end{array}$ & $\begin{array}{c}-6.6534^{* *} \\
(0.0862)\end{array}$ & $\begin{array}{c}-5.8014^{* *} \\
(0.0919)\end{array}$ & $\begin{array}{l}-6.5492^{* *} \\
(0.1110)\end{array}$ \\
\hline
\end{tabular}

Notes: The samples include customers sent a promo code in the respective experiment. The unit of analysis is the customer, the dependent variable being an indicator for whether a customer took up the promo code. Logistic regressions are employed. The indicator variables starting with “ $i$, takes the value of one just for the respective promo subgroups. $\left(* * \mathrm{p}<0.01,{ }^{*} \mathrm{p}<0.05,+\mathrm{p}<0\right.$. 
Table 3a. Longitudinal patterns in average daily bookings: Experiments 1 and 2

\begin{tabular}{|c|c|c|c|c|c|c|c|c|c|c|c|c|c|c|c|c|c|c|c|}
\hline \multicolumn{10}{|c|}{ EXPERIMENT \#1 } & \multicolumn{10}{|c|}{ EXPERIMENT \#2 } \\
\hline \multirow[b]{2}{*}{ Group } & \multicolumn{3}{|c|}{$\begin{array}{l}\text { Take-up Customers } \\
(\mathrm{N}=613)\end{array}$} & \multicolumn{3}{|c|}{$\begin{array}{l}\text { All Customers } \\
(\mathrm{N}=168,504)\end{array}$} & \multicolumn{3}{|c|}{$\begin{array}{l}\text { Active Customers } \\
\qquad(\mathrm{N}=103,218)\end{array}$} & \multirow[b]{2}{*}{ Group } & \multicolumn{3}{|c|}{$\begin{array}{l}\text { Take-up Customers } \\
\text { ( } \mathrm{N}=392)\end{array}$} & \multicolumn{3}{|c|}{$\begin{array}{l}\text { All Customers } \\
(\mathrm{N}=\mathbf{1 4 5 , 8 5 7 )}\end{array}$} & \multicolumn{3}{|c|}{$\begin{array}{l}\text { Active Customers } \\
(\mathrm{N}=\mathbf{8 6 , 4 3 9 )}\end{array}$} \\
\hline & Pre & During & Post & Pre & During & Post & Pre & During & Post & & Pre & During & Post & Pre & During & Post & Pre & During & Post \\
\hline $1 \mathrm{Nepal}$ & 0.357 & 0.528 & 0.323 & 0.091 & 0.091 & 0.080 & 0.151 & 0.141 & 0.122 & $1 \mathrm{sms}$ & 0.302 & 0.526 & 0.290 & 0.092 & 0.090 & 0.081 & 0.156 & 0.143 & 0.127 \\
\hline $2 s g d$ & 0.227 & 0.453 & 0.236 & 0.092 & 0.093 & 0.080 & 0.154 & 0.143 & 0.121 & $7 s m s$ & 0.233 & 0.425 & 0.217 & 0.088 & 0.087 & 0.077 & 0.150 & 0.139 & 0.120 \\
\hline Nepal3sgd & 0.301 & 0.500 & 0.278 & 0.091 & 0.092 & 0.082 & 0.154 & 0.143 & 0.126 & $10 \mathrm{ff}$ & 0.210 & 0.414 & 0.221 & 0.086 & 0.083 & 0.076 & 0.147 & 0.132 & 0.120 \\
\hline $4 s g d$ & 0.252 & 0.439 & 0.218 & 0.093 & 0.095 & 0.082 & 0.154 & 0.145 & 0.125 & & & & & & & & & & \\
\hline Nepal5sgd & 0.234 & 0.408 & 0.233 & 0.088 & 0.091 & 0.080 & 0.150 & 0.142 & 0.122 & & & & & & & & & & \\
\hline \multicolumn{4}{|c|}{ No promocode } & 0.093 & 0.095 & 0.083 & 0.154 & 0.147 & 0.126 & \multicolumn{4}{|c|}{ No promocode } & 0.090 & 0.088 & 0.080 & 0.154 & 0.140 & 0.125 \\
\hline \multicolumn{4}{|l|}{ No SMS } & 0.089 & 0.090 & 0.079 & 0.149 & 0.139 & 0.120 & \multicolumn{4}{|c|}{ NoSMS } & 0.088 & 0.086 & 0.078 & 0.151 & 0.137 & 0.122 \\
\hline
\end{tabular}

Notes: See Table A-3 for the exact dates used to calculate the average of daily taxi bookings for the "pre" period (4 weeks), "during" period (5 days) and "post" period (4 weeks) for the experiment.

Table 3b. Longitudinal patterns in average daily bookings: Experiment 3

\begin{tabular}{|c|c|c|c|c|c|c|c|c|c|c|c|c|}
\hline \multicolumn{13}{|c|}{ EXPERIMENT \#3 } \\
\hline \multirow[b]{2}{*}{ Group } & \multicolumn{3}{|c|}{$\begin{array}{l}\text { Take-up Customers } \\
\qquad(\mathrm{N}=3,351)\end{array}$} & \multicolumn{3}{|c|}{$\begin{array}{l}\text { All Customers } \\
(\mathrm{N}=\mathbf{2 6 0 , 5 0 4 )}\end{array}$} & \multicolumn{3}{|c|}{$\begin{array}{l}\text { Active Customers } \\
(\mathrm{N}=\mathbf{1 2 8 , 2 9 3 )}\end{array}$} & \multicolumn{3}{|c|}{$\begin{array}{l}\text { Multi-Promo Customers } \\
\qquad(\mathrm{N}=120,242)\end{array}$} \\
\hline & Pre & During & Post & Pre & During & Post & Pre & During & Post & Pre & During & Post \\
\hline 1give & 0.384 & 0.575 & 0.397 & 0.091 & 0.099 & 0.093 & 0.183 & 0.190 & 0.173 & 0.090 & 0.097 & 0.092 \\
\hline 5give & 0.324 & 0.574 & 0.328 & 0.088 & 0.097 & 0.091 & 0.181 & 0.188 & 0.172 & 0.089 & 0.098 & 0.090 \\
\hline $10 f f$ & 0.318 & 0.543 & 0.331 & 0.091 & 0.103 & 0.093 & 0.184 & 0.198 & 0.175 & 0.092 & 0.105 & 0.094 \\
\hline $5 \circ f f$ & 0.261 & 0.495 & 0.277 & 0.086 & 0.106 & 0.091 & 0.175 & 0.202 & 0.170 & 0.089 & 0.108 & 0.093 \\
\hline $100 \mathrm{ff}$ & 0.228 & 0.438 & 0.254 & 0.092 & 0.116 & 0.095 & 0.186 & 0.216 & 0.175 & 0.091 & 0.116 & 0.093 \\
\hline No promocode & & & & 0.089 & 0.095 & 0.091 & 0.180 & 0.184 & 0.171 & 0.088 & 0.095 & 0.089 \\
\hline No SMS & & & & 0.091 & 0.099 & 0.092 & 0.185 & 0.191 & 0.173 & 0.089 & 0.099 & 0.088 \\
\hline
\end{tabular}

Notes: See Table A-3 for the exact dates used to calculate the average of daily taxi bookings for the "pre" period (4 weeks), "during" period ( 5 days) and "post" period (4 weeks) for the experiment. 


\section{Table 4. Estimating overall treatment effects using panel data: Experiments 1 and 2}

\begin{tabular}{|c|c|c|c|c|c|c|c|c|}
\hline \multirow{3}{*}{$\begin{array}{l}\text { Customer Sample: } \\
\text { Dependent Variable: }\end{array}$} & \multicolumn{4}{|c|}{ EXPERIMENT \#1 } & \multicolumn{4}{|c|}{ EXPERIMENT \#2 } \\
\hline & \multicolumn{2}{|c|}{ All Customers } & \multicolumn{2}{|c|}{ Active Customers } & \multicolumn{2}{|c|}{ All customers } & \multicolumn{2}{|c|}{ Active customers } \\
\hline & $\begin{array}{l}\text { Daily Bookings } \\
\text { (1) }\end{array}$ & $\begin{array}{l}\text { Daily Fare } \\
\text { (2) }\end{array}$ & $\begin{array}{l}\text { Daily Bookings } \\
\text { (3) }\end{array}$ & $\begin{array}{l}\text { Daily Fare } \\
\text { (4) }\end{array}$ & $\begin{array}{c}\text { Daily Bookings } \\
\text { (5) }\end{array}$ & $\begin{array}{l}\text { Daily Fare } \\
\text { (6) }\end{array}$ & $\begin{array}{c}\text { Daily Bookings } \\
\text { (7) }\end{array}$ & $\begin{array}{c}\text { Daily Fare } \\
(8)\end{array}$ \\
\hline \multicolumn{9}{|l|}{ EXPERIMENT \#1 } \\
\hline \multicolumn{9}{|l|}{ Promotion Period Effects: } \\
\hline t_1Nepal (SGD 1 to Nepal relief) & $\begin{array}{r}-0.0008 \\
(0.0015)\end{array}$ & $\begin{array}{r}-0.0151 \\
(0.0256)\end{array}$ & $\begin{array}{r}-0.0002 \\
(0.0023)\end{array}$ & $\begin{array}{l}-0.0056 \\
(0.0407)\end{array}$ & & & & \\
\hline t_ 2 sgd (SGD 2 to Nepal relief) & $\begin{array}{l}-0.0001 \\
(0.0015)\end{array}$ & $\begin{array}{l}-0.0096 \\
(0.0270)\end{array}$ & $\begin{array}{l}-0.0002 \\
(0.0024)\end{array}$ & $\begin{array}{l}-0.0131 \\
(0.0431)\end{array}$ & & & & \\
\hline t_Nepal3sgd (SGD 3 to Nepal relief) & $\begin{array}{l}-0.0008 \\
(0.0015\end{array}$ & $\begin{array}{l}-0.0316 \\
(0.0255)\end{array}$ & $\begin{array}{l}-0.0008 \\
(0.0024)\end{array}$ & -0.0411 & & & & \\
\hline t_ 4 sgd (SGD 4 to Nepal relief) & $\begin{array}{c}0.0007 \\
(0.0014)\end{array}$ & $\begin{array}{l}-0.0028 \\
(0.0255)\end{array}$ & $\begin{array}{c}0.0016 \\
(0.0023)\end{array}$ & $\begin{array}{c}0.0045 \\
(0.0405)\end{array}$ & & & & \\
\hline t_Nepal5sgd (SGD 5 to Nepal relief) & $\begin{array}{l}0.0017 \\
(0.014)\end{array}$ & $\begin{array}{l}0.0213 \\
(0.0259)\end{array}$ & 0.0028 & $\begin{array}{l}0.0323 \\
(0.0416)\end{array}$ & & & & \\
\hline$t_{-} N O C O D E$ & $\begin{array}{c}0.0013 \\
(0.0015)\end{array}$ & $\begin{array}{c}0.0023 \\
(0.0260)\end{array}$ & $\begin{array}{c}0.0027 \\
(0.0024)\end{array}$ & $\begin{array}{c}0.0170 \\
(0.0412)\end{array}$ & & & & \\
\hline \multicolumn{9}{|l|}{ Post-Promotion Effects: } \\
\hline p_1Nepal (SGD 1 to Nepal relief) & $\begin{array}{c}-0.0007 \\
(0.0010)\end{array}$ & $\begin{array}{l}-0.0150 \\
(0.0178)\end{array}$ & $\begin{array}{l}-0.0006 \\
(0.0016)\end{array}$ & $\begin{array}{l}-0.0115 \\
(0.0284)\end{array}$ & & & & \\
\hline$p_{-} 2 s g d$ (SGD 2 to Nepal relief) & $\begin{array}{c}-0.0020+ \\
(0.0010)\end{array}$ & $\begin{array}{c}-0.0320+ \\
(0.0191)\end{array}$ & $\begin{array}{l}-0.0033^{*} \\
(0.0017)\end{array}$ & $\begin{array}{l}-0.0492 \\
(0.0306)\end{array}$ & & & & \\
\hline P_Nepal3sgd (SGD 3 to Nepal relief) & 0.0007 & 0.0146 & 0.0007 & 0.0133 & & & & \\
\hline$p_{-} 4 \operatorname{sgd}(S G D 4$ to Nepal relief) & -0.0004 & -0.0176 & 0.0001 & $\begin{array}{l}(0.0322) \\
-0.0169\end{array}$ & & & & \\
\hline & $(0.0011)$ & $(0.0183)$ & $(0.0017)$ & $(0.0290)$ & & & & \\
\hline p_Nepal5sgd (SGD 5 to Nepal relief) & 0.0009 & 0.0160 & 0.0014 & 0.0289 & & & & \\
\hline & $(0.0011)$ & $(0.0184)$ & $(0.0017)$ & $(0.0295)$ & & & & \\
\hline P_NOCODE & 0.0003 & 0.0078 & 0.0013 & 0.0308 & & & & \\
\hline & $(0.0011)$ & $(0.0181)$ & $(0.0017)$ & $(0.0289)$ & & & & \\
\hline \multicolumn{9}{|l|}{ EXPERIMENT \#2 } \\
\hline \multicolumn{9}{|l|}{ Promotion Period Effects: } \\
\hline t__sms (SGD 1 to Nepal relief) & & & & & $\begin{array}{c}0.0006 \\
(0.0013)\end{array}$ & $\begin{array}{l}-0.2354 \\
(0.2534)\end{array}$ & $\begin{array}{c}0.0007 \\
(0.0021)\end{array}$ & $\begin{array}{l}-0.4021 \\
(0.4306)\end{array}$ \\
\hline t_ 7 sms (SGD 7 to Nepal relief) & & & & & 0.0016 & 0.0277 & 0.0029 & 0.0523 \\
\hline$t_{-} 10 f f(S G D 1$ discount) & & & & & $\begin{array}{l}-0.0006 \\
-100\end{array}$ & -0.0012 & -0.0009 & 0.0015 \\
\hline & & & & & $(0.0020)$ & $(0.0363)$ & $(0.0033)$ & $(0.0600)$ \\
\hline$t_{-} N O C O D E$ & & & & & 0.0001 & 0.0050 & 0.0002 & 0.0140 \\
\hline & & & & & $(0.0012)$ & $(0.0219)$ & $(0.0021)$ & (0.0359) \\
\hline \multicolumn{9}{|l|}{ Post-Promotion Effects: } \\
\hline p_1sms (SGD 1 to Nepal relief) & & & & & $\begin{array}{l}-0.0003 \\
(0.0009)\end{array}$ & $\begin{array}{c}-0.2461 \\
(0.2530)\end{array}$ & $\begin{array}{c}0.0002 \\
(0.0015)\end{array}$ & $\begin{array}{l}-0.4038 \\
(0.4299)\end{array}$ \\
\hline$p_{-} 7 s m s$ (SGD 7 to Nepal relief) & & & & & -0.0006 & -0.0222 & -0.0006 & -0.0265 \\
\hline & & & & & $(0.0009)$ & $(0.0165)$ & $(0.0015)$ & $(0.0270)$ \\
\hline p_1off (SGD 1 discount) & & & & & 0.0008 & 0.0222 & 0.0012 & 0.0326 \\
\hline & & & & & $(0.0015)$ & $(0.0256)$ & $(0.0024)$ & $(0.0419)$ \\
\hline p_NOCODE & & & & & -0.0002 & 0.0092 & -0.0005 & 0.0131 \\
\hline & & 10098 & 6115976 & 6115076 & $(0.0009)$ & $(0.0221)$ & $(0.0015)$ & $(0.0369)$ \\
\hline Number of customers & $10,058,422$ & $10,098,422$ & $0,110,3918$ & $0,115,918$ & $8,823,520$ & $8,823,520$ & 5,199,022 & $5,199,022$ \\
\hline
\end{tabular}

Notes: The unit of analysis in this table is the customer-day. See Table A-3 for the exact date windows. Linear regression models are employed, with customer and calendar date fixed effects and robust standard errors clustered on customer. The omitted (reference) category for both promotion period effect and post-promotion effect indicators is the "No SMS" group. (** $\mathrm{p}<0.01, * \mathrm{p}<0.05,+\mathrm{p}<0.1$ ) 
Table 5. Estimating overall treatment effects using panel data: Experiment 3

\begin{tabular}{|c|c|c|c|c|c|c|}
\hline \multirow{3}{*}{$\begin{array}{l}\text { Customer Sample: } \\
\text { Dependent Variable: }\end{array}$} & \multicolumn{6}{|c|}{ EXPERIMENT \#3 } \\
\hline & \multicolumn{2}{|c|}{ All Customers } & \multicolumn{2}{|c|}{ Active Customers } & \multicolumn{2}{|c|}{ Multi-Promo Sample } \\
\hline & $\begin{array}{c}\text { Daily Bookings } \\
\text { (1) }\end{array}$ & $\begin{array}{c}\text { Daily Fare } \\
\text { (2) }\end{array}$ & $\begin{array}{c}\text { Daily Bookings } \\
\text { (3) }\end{array}$ & $\begin{array}{l}\text { Daily Fare } \\
\text { (4) }\end{array}$ & $\begin{array}{c}\text { Daily Bookings } \\
\text { (5) }\end{array}$ & $\begin{array}{c}\text { Daily Fare } \\
\text { (6) }\end{array}$ \\
\hline \multicolumn{7}{|l|}{ EXPERIMENT \#3 } \\
\hline \multicolumn{7}{|l|}{ Promotion Period Effects: } \\
\hline t_1give (SGD 1 to Singapore Cancer Society) & $\begin{array}{c}0.0002 \\
(0.0013)\end{array}$ & $\begin{array}{c}0.0121 \\
(0.0212)\end{array}$ & $\begin{array}{c}0.0006 \\
(0.0025)\end{array}$ & $\begin{array}{c}0.0276 \\
(0.0417)\end{array}$ & $\begin{array}{l}-0.0029 \\
(0.0024)\end{array}$ & $\begin{array}{c}0.0006 \\
(0.0401)\end{array}$ \\
\hline t_5give (SGD 5 to Singapore Cancer Society) & $\begin{array}{c}0.0010 \\
(0.0013)\end{array}$ & $\begin{array}{c}0.0045 \\
(0.0229)\end{array}$ & $\begin{array}{c}0.0017 \\
(0.0025)\end{array}$ & $\begin{array}{c}0.0038 \\
(0.0456)\end{array}$ & $\begin{array}{l}-0.0005 \\
(0.0024)\end{array}$ & $\begin{array}{c}0.0334 \\
(0.0419)\end{array}$ \\
\hline t__10give (SGD 10 to Singapore Cancer Society) & $\begin{array}{c}0.0004 \\
(0.0022)\end{array}$ & $\begin{array}{l}-0.0053 \\
(0.0355)\end{array}$ & $\begin{array}{c}0.0017 \\
(0.0043)\end{array}$ & $\begin{array}{c}0.0004 \\
(0.0705)\end{array}$ & $\begin{array}{l}-0.0019 \\
(0.0027)\end{array}$ & $\begin{array}{c}-0.0108 \\
(0.0446)\end{array}$ \\
\hline t_1off (SGD 1 discount) & $\begin{array}{l}0.0048^{* *} \\
(0.0013)\end{array}$ & $\begin{array}{l}0.0757^{* *} \\
(0.0209)\end{array}$ & $\begin{array}{l}0.0085^{* *} \\
(0.0025)\end{array}$ & $\begin{array}{l}0.1297^{* *} \\
(0.0411)\end{array}$ & $\begin{array}{c}0.0031 \\
(0.0025)\end{array}$ & $\begin{array}{l}0.0866^{*} \\
(0.0403)\end{array}$ \\
\hline t_5off (SGD 5 discount) & $\begin{array}{l}0.0123^{* *} \\
(0.0027)\end{array}$ & $\begin{array}{l}0.1669^{* *} \\
(0.0438)\end{array}$ & $\begin{array}{l}0.0211^{* *} \\
(0.0054)\end{array}$ & $\begin{array}{l}0.2895^{* *} \\
(0.0862)\end{array}$ & $\begin{array}{l}0.0097^{*} \\
(0.0041)\end{array}$ & $\begin{array}{l}0.1537^{*} \\
(0.0643)\end{array}$ \\
\hline$t$ t_10off (SGD 10 discount) & $\begin{array}{l}0.0153^{* *} \\
(0.0038)\end{array}$ & $\begin{array}{l}0.2021^{* *} \\
(0.0593)\end{array}$ & $\begin{array}{l}0.0233^{* *} \\
(0.0074)\end{array}$ & $\begin{array}{l}0.3174^{* *} \\
(0.1156)\end{array}$ & $\begin{array}{l}0.0148^{* *} \\
(0.0052)\end{array}$ & $\begin{array}{l}0.2061^{*} \\
(0.0803)\end{array}$ \\
\hline$t_{-} N O C O D E$ & $\begin{array}{l}-0.0013 \\
(0.0013)\end{array}$ & $\begin{array}{c}-0.0199 \\
(0.0208)\end{array}$ & $\begin{array}{l}-0.0021 \\
(0.0025)\end{array}$ & $\begin{array}{c}-0.0341 \\
(0.0410)\end{array}$ & $\begin{array}{l}-0.0029 \\
(0.0028)\end{array}$ & $\begin{array}{c}0.0142 \\
(0.0465)\end{array}$ \\
\hline \multicolumn{7}{|l|}{ Post-Promotion Effects: } \\
\hline p_1give (SGD 1 to Singapore Cancer Society) & $\begin{array}{c}0.0012 \\
(0.0009)\end{array}$ & $\begin{array}{c}0.0190 \\
(0.0149)\end{array}$ & $\begin{array}{c}0.0020 \\
(0.0018)\end{array}$ & $\begin{array}{c}0.0300 \\
(0.0290)\end{array}$ & $\begin{array}{c}0.0026 \\
(0.0017)\end{array}$ & $\begin{array}{l}0.0565+ \\
(0.0305)\end{array}$ \\
\hline p_5give (SGD 5 to Singapore Cancer Society) & $\begin{array}{l}0.0018+ \\
(0.0009)\end{array}$ & $\begin{array}{c}0.0115 \\
(0.0165)\end{array}$ & $\begin{array}{l}0.0031+ \\
(0.0018)\end{array}$ & $\begin{array}{c}0.0126 \\
(0.0326)\end{array}$ & $\begin{array}{c}0.0022 \\
(0.0017)\end{array}$ & $\begin{array}{c}0.0430 \\
(0.0309)\end{array}$ \\
\hline p_10give (SGD 10 to Singapore Cancer Society) & $\begin{array}{c}0.0005 \\
(0.0012)\end{array}$ & $\begin{array}{c}0.0470 \\
(0.0396)\end{array}$ & $\begin{array}{c}0.0015 \\
(0.0023)\end{array}$ & $\begin{array}{c}0.1016 \\
(0.0793)\end{array}$ & $\begin{array}{c}0.0025 \\
(0.0019)\end{array}$ & $\begin{array}{l}0.1251+ \\
(0.0692)\end{array}$ \\
\hline p_1off (SGD 1 discount) & $\begin{array}{c}0.0014 \\
(0.0009)\end{array}$ & $\begin{array}{l}0.0262+ \\
(0.0150)\end{array}$ & $\begin{array}{c}0.0027 \\
(0.0018)\end{array}$ & $\begin{array}{c}0.0462 \\
(0.0292)\end{array}$ & $\begin{array}{c}0.0025 \\
(0.0017)\end{array}$ & $\begin{array}{l}0.0584+ \\
(0.0306)\end{array}$ \\
\hline p_5off (SGD 5 discount) & $\begin{array}{l}0.0037+ \\
(0.0019)\end{array}$ & $\begin{array}{l}0.0507+ \\
(0.0297)\end{array}$ & $\begin{array}{l}0.0062+ \\
(0.0037)\end{array}$ & $\begin{array}{c}0.0874 \\
(0.0581)\end{array}$ & $\begin{array}{c}0.0046 \\
(0.0028)\end{array}$ & $\begin{array}{l}0.0900^{*} \\
(0.0450)\end{array}$ \\
\hline p_10off (SGD 10 discount) & $\begin{array}{c}0.0016 \\
(0.0029)\end{array}$ & $\begin{array}{c}0.0049 \\
(0.0426)\end{array}$ & $\begin{array}{c}0.0006 \\
(0.0055)\end{array}$ & $\begin{array}{c}-0.0291 \\
(0.0812)\end{array}$ & $\begin{array}{c}0.0022 \\
(0.0039)\end{array}$ & $\begin{array}{c}0.0440 \\
(0.0600)\end{array}$ \\
\hline p_NOCODE & $\begin{array}{c}0.0011 \\
(0.0009)\end{array}$ & $\begin{array}{c}0.0131 \\
(0.0149)\end{array}$ & $\begin{array}{c}0.0025 \\
(0.0018)\end{array}$ & $\begin{array}{c}0.0302 \\
(0.0292)\end{array}$ & $\begin{array}{c}0.0020 \\
(0.0020)\end{array}$ & $\begin{array}{c}0.0495 \\
(0.0343)\end{array}$ \\
\hline Observations & $15,890,744$ & $15,890,744$ & $7,825,873$ & $7,825,873$ & $7,334,762$ & $7,334,762$ \\
\hline Number of customers & 260,504 & 260,504 & 128,293 & 128,293 & 120,242 & 120,242 \\
\hline
\end{tabular}

Notes: The unit of analysis in this table is the customer-day. See Table A-3 for the exact date windows. Linear regression models are employed, with customer and calendar date fixed effects and robust standard errors clustered on customer. The omitted (reference) category for both promotion period effect and post-promotion effect indicators is the "No SMS" group. (** $\mathrm{p}<0.01, * \mathrm{p}<0.05,+\mathrm{p}<0.1)$ 


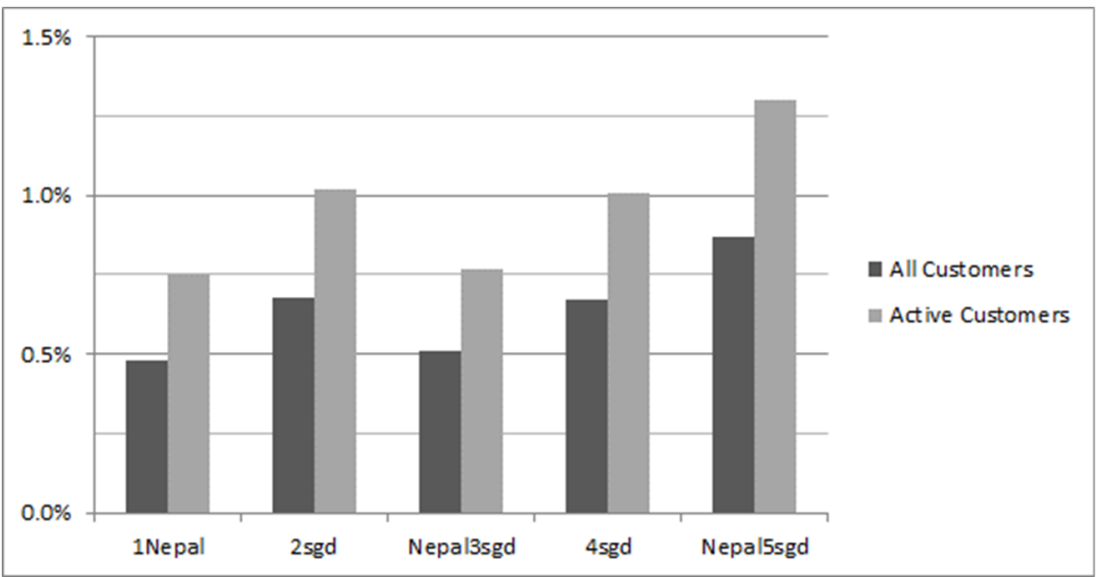

Figure 1a. Promotion take-up rates: Experiment 1

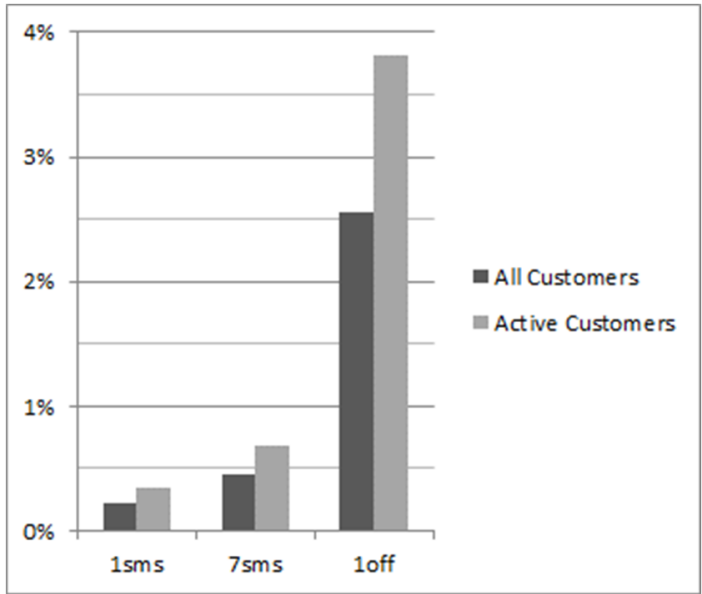

Figure 1b. Promotion take-up rates: Experiment 2

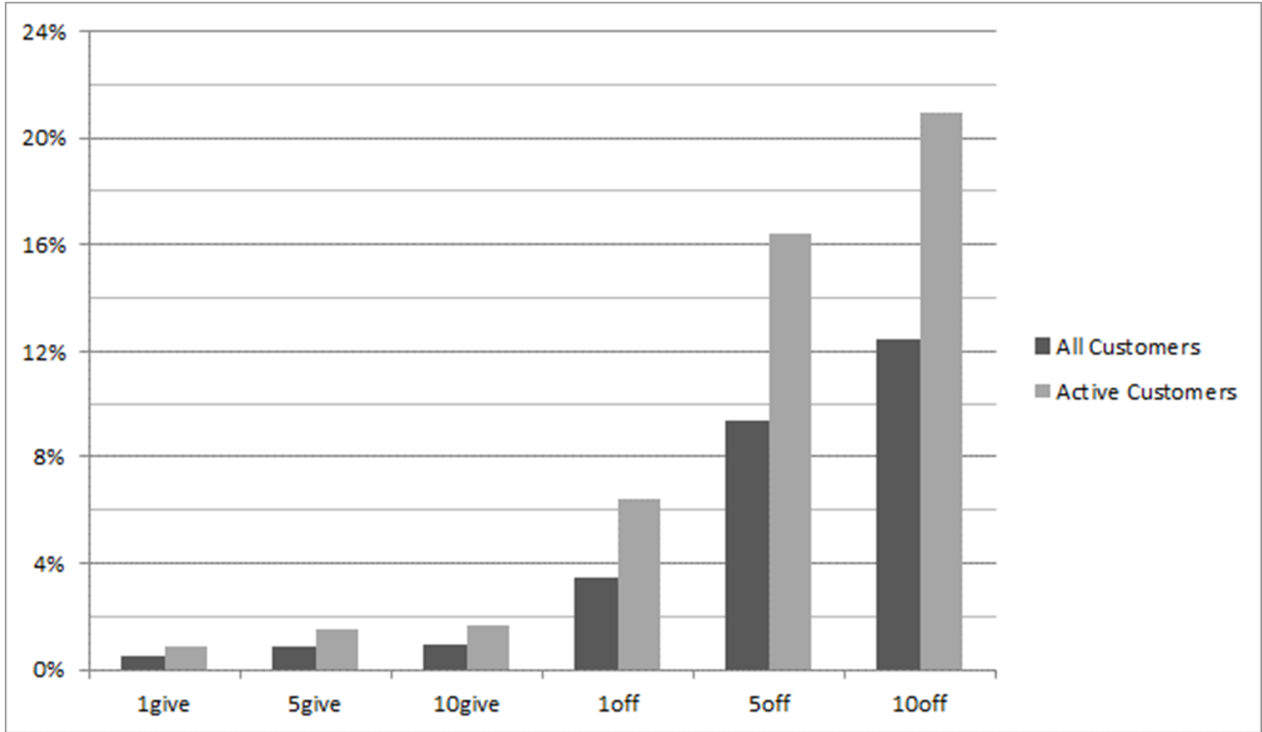

Figure 1c. Promotion take-up rates: Experiment 3 


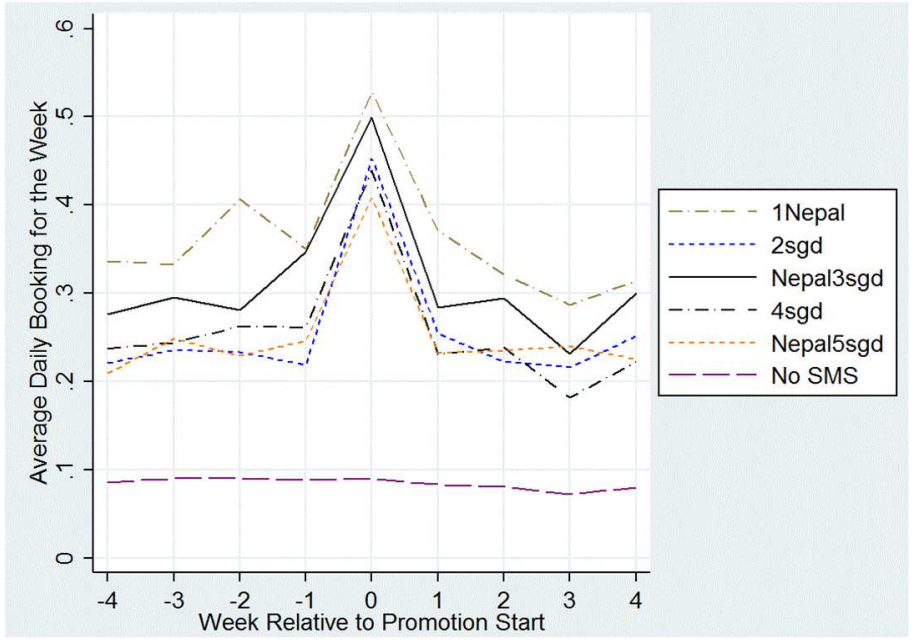

Figure 2a. Taxi booking patterns for customers taking up different promotions: Experiment 1

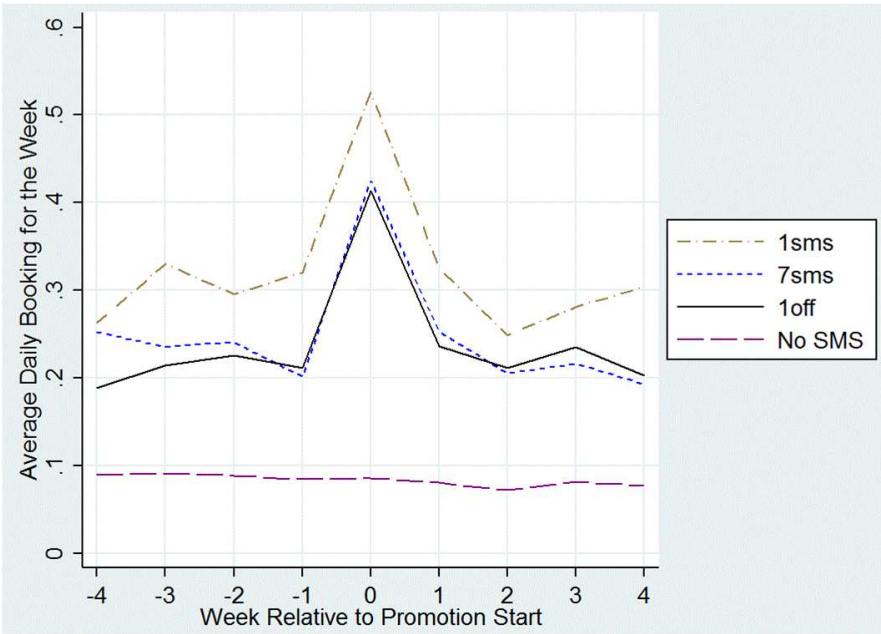

Figure 2b. Taxi booking patterns for customers taking up different promotions: Experiment 2

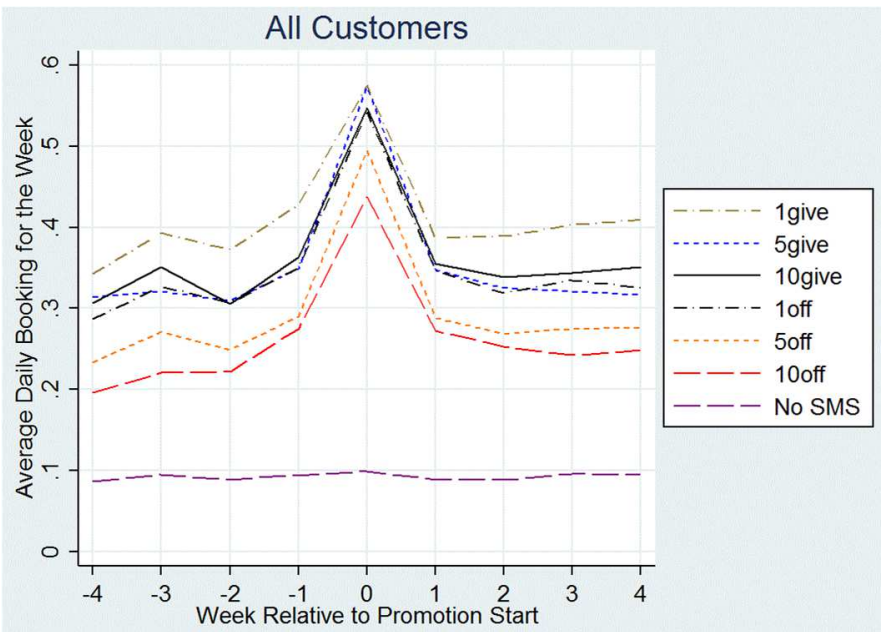

Figure 2c. Taxi booking patterns for customers taking up different promotions: Experiment 3 


\section{ONLINE APPENDIX}

\section{Table A-1a. Exact SMS text for the customer promotions: Experiment 1}

\section{$\underline{1 \text { Nepal }}$}

Key in promo code: 1Nepal and [company name] will donate 1 SGD to Nepal.

[company name] will donate 1 SGD from your next ride booked through our app to aid earthquake relief efforts in Nepal. Book a ride to aid Nepal! Promo ends 31 May and good for one-time use only.

\section{$\underline{2 \text { sgd }}$}

Key in promo code: $\mathbf{2}$ sgd and [company name] will donate 2 SGD to Nepal.

[company name] will donate 2 SGD from your next ride booked through our app to aid earthquake relief efforts in Nepal. Book a ride to aid Nepal! Promo ends 31 May and good for one-time use only.

\section{Nepal3sgd}

Key in promo code: Nepal3sgd and [company name] will donate 3 SGD to Nepal.

[company name] will donate 3 SGD from your next ride booked through our app to aid earthquake relief efforts in Nepal. Book a ride to aid Nepal! Promo ends 31 May and good for one-time use only.

\section{$\underline{4 \text { sgd }}$}

Key in promo code: 4 sgd and [company name] will donate 4 SGD to Nepal.

[company name] will donate 4 SGD from your next ride booked through our app to aid earthquake relief efforts in Nepal. Book a ride to aid Nepal! Promo ends 31 May and good for one-time use only.

\section{Nepal5sgd}

Key in promo code: Nepal5sgd and [company name] will donate 5 SGD to Nepal.

[company name] will donate 5 SGD from your next ride booked through our app to aid earthquake relief efforts in Nepal. Book a ride to aid Nepal! Promo ends 31 May and good for one-time use only.

\section{No Code}

[company name] offers safety, speed \& certainty to bring you to your destination with just a few taps. What are you waiting for? Book your ride now! 


\section{Table A-1b. Exact SMS text for the customer promotions: Experiment 2}

$\underline{\text { 1sms }}$

Key in promo code: 1sms and [company name] will donate 1 SGD to Nepal.

[company name] will donate 1 SGD from your next ride booked through our app to aid earthquake relief efforts in Nepal. Book a ride to aid Nepal!

Promo ends 8 June and good for one-time use only.

\section{$\underline{7 \mathbf{s m s}}$}

Key in promo code: 7sms and [company name] will donate 7 SGD to Nepal.

[company name] will donate 7 SGD from your next ride booked through our app to aid earthquake relief efforts in Nepal. Book a ride to aid Nepal!

Promo ends 8 June and good for one-time use only.

\section{$\underline{10 f f}$}

Key in promo code: 1 off and receive 1 SGD off your next ride.

[company name] offers safety, speed \& certainty to bring you to your destination with just a few taps. What are you waiting for? Book your ride now! Promo ends 8 June and good for one-time use only.

\section{No Code}

[company name] offers safety, speed \& certainty to bring you to your destination with just a few taps. What are you waiting for? Book your ride now! 


\section{Table A-1c. Exact SMS text for the customer promotions: Experiment 3}

\section{$\underline{\text { give }}$}

Key in promo code: 1give for your next booking through our app and [company name] will donate 1 SGD to the Singapore Cancer Society (promo ends 11 Oct). [company name] offers safety, speed \& certainty to bring you to your destination with just a few taps. What are you waiting for? Book your ride now!

\section{$\underline{\text { Sgive }}$}

Key in promo code: 5 give for your next booking through our app and [company name] will donate 5 SGD to the Singapore Cancer Society (promo ends 11 Oct). [company name] offers safety, speed \& certainty to bring you to your destination with just a few taps. What are you waiting for? Book your ride now!

\section{$\underline{\text { 10give }}$}

Key in promo code: 10give for your next booking through our app and [company name] will donate 10 SGD to the Singapore Cancer Society (promo ends 11 Oct).

[company name] offers safety, speed \& certainty to bring you to your destination with just a few taps. What are you waiting for? Book your ride now!

\section{$\underline{10 f f}$}

Key in promo code: 1off for your next booking through our app and [company name] will give you 1 SGD off for that ride (promo ends 11 Oct).

[company name] offers safety, speed \& certainty to bring you to your destination with just a few taps. What are you waiting for? Book your ride now!

\section{$\underline{\text { 5off }}$}

Key in promo code: 5off for your next booking through our app and [company name] will give you up to 5 SGD off for that ride (promo ends 11 Oct). [company name] offers safety, speed \& certainty to bring you to your destination with just a few taps. What are you waiting for? Book your ride now!

\section{$\underline{10 o f f}$}

Key in promo code: 10off for your next booking through our app and [company name] will give you up to 10 SGD off for that ride (promo ends 11 Oct). [company name] offers safety, speed \& certainty to bring you to your destination with just a few taps. What are you waiting for? Book your ride now!

\section{No Code}

[company name] offers safety, speed \& certainty to bring you to your destination with just a few taps. What are you waiting for? Book your ride now! 
Table A-2. Overlap of customers in Experiment 3 with those in Experiments 1 and 2

\begin{tabular}{|c|c|c|c|c|c|c|c|c|c|c|c|c|}
\hline \multirow[b]{2}{*}{ Experiment 3 Group } & \multicolumn{7}{|c|}{ Prior SMS with a promo code (in Experiment 1 or 2) } & \multirow[b]{2}{*}{ loff } & \multicolumn{2}{|c|}{ Prior SMS with no code } & \multirow[t]{2}{*}{ No prior SMS } & \multirow[t]{2}{*}{ Tota } \\
\hline & $1 \mathrm{Nepal}$ & $2 s g d$ & Nepal3sgd & $4 s g d$ & Nepal5sgd & $1 \mathrm{sms}$ & $7 s m s$ & & Experiment 1 & Experiment 2 & & \\
\hline \multicolumn{13}{|l|}{ Charity promotion: } \\
\hline Igive & 3,660 & 3,660 & 3,660 & 3,660 & 3,660 & 5,380 & 5,380 & 1,540 & 3,660 & 5,380 & 10,360 & 50,000 \\
\hline 5give & 3,660 & 3,660 & 3,660 & 3,660 & 3,660 & 5,380 & 5,380 & 1,540 & 3,660 & 5,380 & 10,360 & 50,000 \\
\hline 10give & 1,464 & 1,464 & 1,464 & 1,464 & 1,464 & 2,152 & 2,152 & 616 & 1,464 & 2,152 & 4,144 & 20,000 \\
\hline \multicolumn{13}{|l|}{ Discount promotion: } \\
\hline $10 f f$ & 3,660 & 3,660 & 3,660 & 3,660 & 3,660 & 5,380 & 5,380 & 1,540 & 3,660 & 5,380 & 10,360 & 50,000 \\
\hline $5 o f f$ & 366 & 366 & 366 & 366 & 366 & 538 & 538 & 154 & 366 & 538 & 1,036 & 5,000 \\
\hline $100 \mathrm{ff}$ & 183 & 183 & 183 & 183 & 183 & 269 & 269 & 77 & 183 & 269 & 518 & 2,500 \\
\hline Subtotal for promo codes & 12,993 & 12,993 & 12,993 & 12,993 & 12,993 & 19,099 & 19,099 & 5,467 & 12,993 & 19,099 & 36,778 & 177,500 \\
\hline \multicolumn{13}{|l|}{ No promotion (controls): } \\
\hline SMS without promocode & 3,660 & 3,660 & 3,660 & 3,660 & 3,660 & 5,380 & 5,380 & 1,540 & 3,660 & 5,380 & 10,360 & 50,000 \\
\hline No SMS at all & 2,455 & 2,455 & 2,455 & 2,455 & 2,455 & 3,521 & 3,521 & 993 & 2,454 & 3,521 & 6,719 & 33,004 \\
\hline Total sample size & 19,108 & 19,108 & 19,108 & 19,108 & 19,108 & 28,000 & 28,000 & 8,000 & 19,107 & 28,000 & 53,857 & 260,504 \\
\hline
\end{tabular}


Table A-3. Construction of panel datasets for the three experiments

EXPERIMENT\# 1 (168,504 unique customers):

Historical Data 1Jan-29Apr

Pre-Promotion Window 30Apr-26May (28 days)

Promotion Window

27May-31May (5 days)

Post-Promotion Window

\section{EXPERIMENT \#2 (145,857 unique customers):}

\begin{tabular}{|c|c|c|c|}
\hline Historical Data & 1Jan-06May & & \\
\hline Pre-Promotion Window & & 07May-3Jun (28 days) & \\
\hline Promotion Window & & & 04Jun-08Jun (5 days) \\
\hline
\end{tabular}

Promotion Window

09Jun-06Jul (28 days)

\section{EXPERIMENT \#3 (260,504 unique customers):}

\section{Historical Data \\ 01Jan-07Sep}

Pre-Promotion Window

Promotion Window

Post-Promotion Window

08Sep-050ct (28 days)

060ct-100ct ( 5 days) 
Table A-4. Customer characteristics: Balance across treatment groups

\begin{tabular}{|c|c|c|c|c|c|c|c|c|c|}
\hline & \multicolumn{3}{|c|}{ EXPERIMENT \#1 } & \multicolumn{3}{|c|}{ EXPERIMENT \#2 } & \multicolumn{3}{|c|}{ EXPERIMENT \#3 } \\
\hline & $N$ & Mean & Std Dev & $N$ & Mean & Std Dev & $N$ & Mean & Std Dev \\
\hline \multicolumn{10}{|c|}{ Customers sent SMS with a charity promo } \\
\hline recent booking history & 95,540 & $3.21^{+}$ & 6.32 & 56,000 & 3.24 & 5.96 & 120,000 & 3.07 & 6.37 \\
\hline customer tenure & 95,540 & 0.53 & 0.38 & 56,000 & 0.55 & 0.38 & 120,000 & 0.89 & 0.38 \\
\hline past promotion takeup & 95,540 & $0.07^{+}$ & 0.26 & 56,000 & 0.08 & 0.27 & 120,000 & 0.23 & 0.42 \\
\hline apple device & 95,540 & 0.59 & 0.49 & 56,000 & 0.58 & 0.49 & 120,000 & 0.59 & 0.49 \\
\hline \multicolumn{10}{|c|}{ Customers sent SMS with a discount promo } \\
\hline recent booking history & & & & 8,000 & 3.09 & 5.61 & 57,500 & 3.08 & 6.88 \\
\hline customer tenure & & & & 8,000 & 0.55 & 0.38 & 57,500 & 0.89 & 0.38 \\
\hline past promotion takeup & & & & 8,000 & 0.08 & 0.27 & 57,500 & 0.24 & 0.42 \\
\hline apple device & & & & 8,000 & $0.57 *$ & 0.50 & 57,500 & $0.59^{+}$ & 0.49 \\
\hline \multicolumn{10}{|c|}{ Customers sent SMS without any promo code } \\
\hline recent booking history & 19,107 & $3.26^{*}$ & 5.98 & 28,000 & $3.27^{+}$ & 6.08 & 50,000 & $3.02^{+}$ & 6.21 \\
\hline customer tenure & 19,107 & 0.52 & 0.38 & 28,000 & 0.55 & 0.37 & 50,000 & 0.88 & 0.38 \\
\hline past promotion takeup & 19,107 & 0.07 & 0.26 & 28,000 & 0.08 & 0.27 & 50,000 & 0.23 & 0.42 \\
\hline apple device & 19,107 & 0.59 & 0.49 & 28,000 & 0.59 & 0.49 & 50,000 & 0.59 & 0.49 \\
\hline \multicolumn{10}{|c|}{ Customers not sent any SMS } \\
\hline recent booking history & 53,857 & 3.15 & 5.76 & 53,857 & 3.19 & 5.89 & 33,004 & 3.10 & 6.48 \\
\hline customer tenure & 53,857 & 0.52 & 0.38 & 53,857 & 0.55 & 0.38 & 33,004 & 0.89 & 0.38 \\
\hline past promotion takeup & 53,857 & 0.07 & 0.25 & 53,857 & 0.08 & 0.27 & 33,004 & 0.23 & 0.42 \\
\hline apple device & 53,857 & 0.59 & 0.49 & 53,857 & 0.59 & 0.49 & 33,004 & 0.59 & 0.49 \\
\hline
\end{tabular}

Notes: The statistics are reported for the "All Customers" sample for each experiment. Specific promo groups within "charity promo" and "discount promo" categories not shown for brevity. Note that the mean value for customer tenure varies across experiments because the experiments were carried out sequentially (so the same customer would have been with the firm longer in a later experiment) Cases where a t-test rejects equality of means for a variable relative to the "No SMS" group are clearly indicated (** $\mathrm{p}<0.01, * \mathrm{p}<0.05,+\mathrm{p}<0.1)$ 
Table A-5. Customer characteristics: Selection effects in promotion take-up

\begin{tabular}{|c|c|c|c|c|c|c|c|c|c|}
\hline & \multicolumn{3}{|c|}{ EXPERIMENT \#1 } & \multicolumn{3}{|c|}{ EXPERIMENT \#2 } & \multicolumn{3}{|c|}{ EXPERIMENT \#3 } \\
\hline & $N$ & Mean & Std Dev & $N$ & Mean & Std Dev & $N$ & Mean & Std Dev \\
\hline \multicolumn{10}{|c|}{ Customers taking up a charity promo } \\
\hline recent booking history & 613 & $8.66^{* *}$ & 9.36 & 188 & $8.71 * *$ & 9.25 & 838 & $11.28 * *$ & 11.23 \\
\hline customer tenure & 613 & $0.57^{* *}$ & 0.39 & 188 & $0.65 * *$ & 0.40 & 838 & $0.93 * *$ & 0.38 \\
\hline past promotion takeup & 613 & $0.17^{* *}$ & 0.38 & 188 & $0.20 * *$ & 0.40 & 838 & $0.63 * *$ & 0.48 \\
\hline apple device & 613 & $0.69^{* *}$ & 0.46 & 188 & $0.84 * *$ & 0.37 & 838 & $0.67 * *$ & 0.47 \\
\hline \multicolumn{10}{|c|}{ Customers taking up a discount promo } \\
\hline customer tenure & & & & 204 & $0.63^{* *}$ & 0.40 & 2,513 & $0.96^{* *}$ & 0.39 \\
\hline past promotion takeup & & & & 204 & $0.22 * *$ & 0.40 & 2,513 & $0.60^{* *}$ & 0.49 \\
\hline apple device & & & & 204 & 0.55 & 0.37 & 2,513 & $0.67^{* *}$ & 0.47 \\
\hline
\end{tabular}

Notes: The statistics are reported for the "All Customers" sample for each experiment. Specific promo groups within "charity promo" and "discount promo" categories not shown for brevity. Cases where a t-test rejects equality of means for a variable relative to the overall "No SMS" group from Table A-4 are clearly indicated $(* * \mathrm{p}<0.01, * \mathrm{p}<0.05,+\mathrm{p}<0.1)$. 
Table A-6a. Longitudinal patterns in average daily spending (SGD): Experiments 1 and 2

\begin{tabular}{|c|c|c|c|c|c|c|c|c|c|c|c|c|c|c|c|c|c|c|c|}
\hline \multirow[b]{3}{*}{ Group } & \multicolumn{6}{|c|}{ EXPERIMENT \#1 } & & & & \multicolumn{10}{|c|}{ EXPERIMENT \#2 } \\
\hline & \multicolumn{3}{|c|}{$\begin{array}{l}\text { Take-up Customers } \\
(\mathrm{N}=613)\end{array}$} & \multicolumn{3}{|c|}{$\begin{array}{l}\text { All Customers } \\
(\mathrm{N}=168,504)\end{array}$} & \multicolumn{3}{|c|}{$\begin{array}{l}\text { Active Customers } \\
(\mathrm{N}=103,218)\end{array}$} & \multirow[b]{2}{*}{ Group } & \multicolumn{3}{|c|}{$\begin{array}{c}\text { Take-up Customers } \\
(\mathrm{N}=392) \\
\end{array}$} & \multicolumn{3}{|c|}{$\begin{array}{c}\text { All Customers } \\
(\mathrm{N}=\mathbf{1 4 5}, \mathbf{8 5 7})\end{array}$} & \multicolumn{3}{|c|}{$\begin{array}{l}\text { Active Customers } \\
\qquad(\mathrm{N}=\mathbf{8 6 , 4 3 9 )}\end{array}$} \\
\hline & Pre & During & Post & Pre & During & Post & Pre & During & Post & & Pre & During & Post & Pre & During & Post & Pre & During & Post \\
\hline 1Nepal & 5.60 & 9.09 & 5.18 & 1.49 & 1.51 & 1.33 & 2.49 & 2.33 & 2.00 & $1 \mathrm{sms}$ & 5.75 & 9.42 & 5.27 & 1.74 & 1.46 & 1.33 & 2.98 & 2.31 & 2.09 \\
\hline $2 s g d$ & 3.31 & 6.92 & 3.50 & 1.50 & 1.53 & 1.32 & 2.51 & 2.35 & 1.99 & $7 s m s$ & 4.04 & 7.49 & 3.76 & 1.45 & 1.43 & 1.27 & 2.47 & 2.27 & 1.97 \\
\hline Nepal3sgd & 5.06 & 8.46 & 4.63 & 1.50 & 1.51 & 1.37 & 2.54 & 2.35 & 2.08 & $10 f f$ & 3.44 & 7.06 & 3.56 & 1.40 & 1.36 & 1.27 & 2.40 & 2.16 & 1.97 \\
\hline $4 s g d$ & 4.04 & 7.35 & 3.55 & 1.52 & 1.56 & 1.35 & 2.52 & 2.38 & 2.04 & & & & & & & & & & \\
\hline Nepal5sgd & 3.71 & 6.98 & 3.78 & 1.46 & 1.52 & 1.33 & 2.47 & 2.35 & 2.03 & & & & & & & & & & \\
\hline \multicolumn{4}{|c|}{ No promocode } & 1.51 & 1.56 & 1.37 & 2.51 & 2.38 & 2.07 & No pro & ocode & & & 1.48 & 1.44 & 1.33 & 2.53 & 2.29 & 2.07 \\
\hline \multicolumn{4}{|c|}{ No SMS } & 1.45 & 1.49 & 1.30 & 2.43 & 2.28 & 1.96 & No SMS & & & & 1.44 & 1.40 & 1.28 & 2.47 & 2.21 & 2.00 \\
\hline
\end{tabular}

Notes: See Table A-3 for the exact dates used to calculate the average of daily spending (SGD) for the "pre" period (4 weeks), "during" period (5 days) and "post" period (4 weeks) for the experiment.

Table A-6b. Longitudinal patterns in average daily spending (SGD): Experiment 3

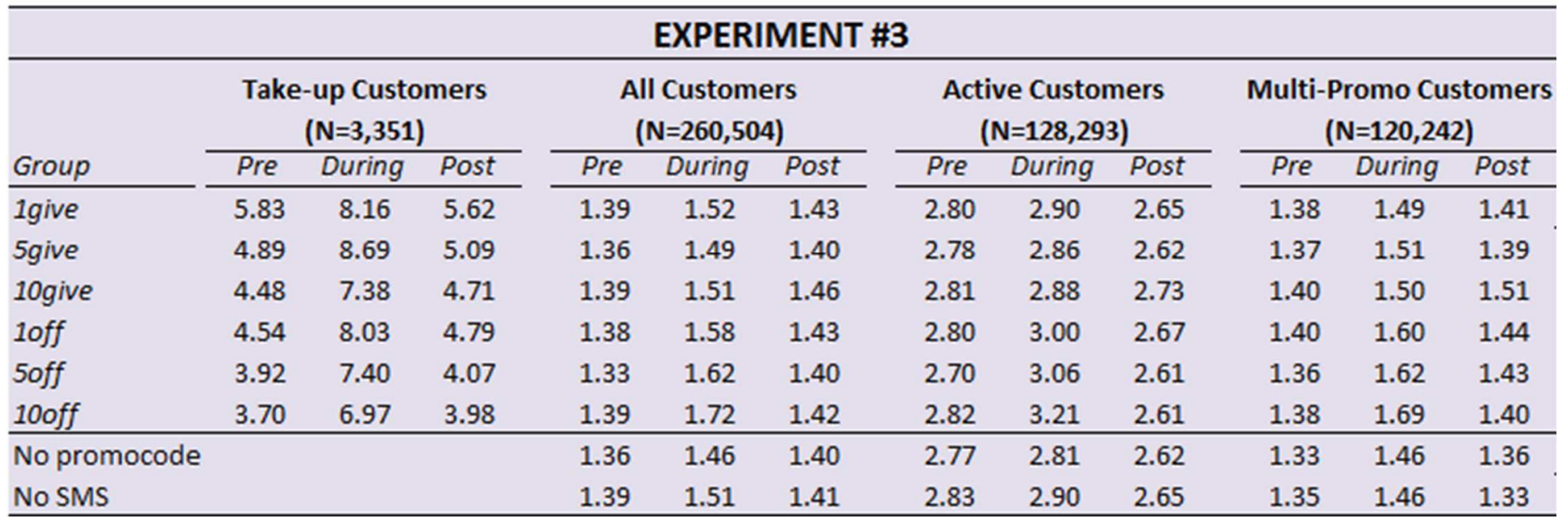

Notes: See Table A-3 for the exact dates used to calculate the average of daily spending (SGD) for the "pre" period (4 weeks), "during" period (5 days) and "post" period (4 weeks) for the experiment. 